Original paper

\title{
The Sklené garnet peridotite: petrology, geochemistry, and structure of a mantle-derived boudin in Moldanubian granulite
}

\author{
Gordon MEDARIS, Jr. ${ }^{*}$, Lukáš ACKERMAN²,3, Emil JELÍNEK4, Virginia TOY5, Wolfgang \\ SIEBEL ${ }^{6}$, Basil TIKOFF ${ }^{1}$
}

${ }^{1}$ Department of Geoscience, University of Wisconsin-Madison, 1215 West Dayton, Madison, WI 53706, USA; medaris@geology.wisc.edu

${ }^{2}$ Institute of Geology v.v.i., Academy of Sciences of the Czech Republic, Rozvojová 269, 16500 Prague 6, Czech Republic

${ }^{3}$ Czech Geological Survey, Geologická 6, 15000 Prague 5, Czech Republic

${ }^{4}$ Institute of Geochemistry, Mineralogy and Mineral Resources, Charles University, Albertov 6, 12843 Prague 2, Czech Republic

${ }^{5}$ Geology Department, University of Otago, P.O. Box 56, Dunedin 9054, New Zealand

${ }^{6}$ Institute of Geosciences, Eberhard-Karls University Tübingen, Wilhelmstraße 56, 72074 Tübingen, Germany

* Corresponding author

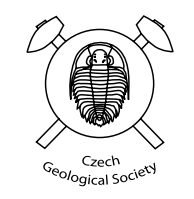

The Moldanubian Sklené garnet peridotite, which preserves mineralogical, geochemical, and structural evidence for a protracted mantle evolution, is a small boudin $(\sim 1 \mathrm{~m})$ enclosed by granulite of the Gföhl Assemblage. The peridotite has a porphyroclastic texture, in which large garnet and smaller olivine and pyroxene porphyroclasts (Stage 1) reside in a fine-grained, recrystallized matrix of olivine, pyroxene, and pargasitic amphibole (Stage 2). Garnet is surrounded by kelyphite, consisting of an outer zone of pargasite and an inner zone of spinel and pyroxene (Stage 3).

Lattice-preferred orientations (LPO) for olivine, orthopyroxene, and clinopyroxene were measured by electron backscatter diffraction. The LPO of olivine (mostly Stage 2) has an [010] maximum parallel to the $\mathrm{Z}$ fabric direction and [100] and [001] girdles in the $\mathrm{X}-\mathrm{Y}$ fabric plane. Both orthopyroxene and clinopyroxene have [010] maxima parallel to $\mathrm{Z}$ and $[001]$ girdles in the $\mathrm{X}-\mathrm{Y}$ plane.

The Sklené peridotite is slightly depleted in incompatible major and minor elements relative to primitive mantle. Whole-rock REE contents are 0.3 to 0.8 times that of primitive mantle, with a convex upward pattern, and Rb, Th, U, $\mathrm{Pb}$, and $\mathrm{Sr}$ show positive anomalies in an extended element plot. Among the highly siderophile elements, Os, Ir, Ru, and Pt are unfractionated, but Pd and Re are significantly depleted. A Sm-Nd garnet-whole rock-clinopyroxene isochron yields a cooling age of $338 \pm 13 \mathrm{Ma}$, and $\varepsilon_{\mathrm{Nd}}$ and $\left({ }^{87} \mathrm{Sr} /{ }^{86} \mathrm{Sr}\right.$ ) i values for clinopyroxene (at $\left.335 \mathrm{Ma}\right)$ are +4.5 and 0.7035 , respectively.

By comparison with other Moldanubian garnet peridotites in the Czech Republic, the Sklené peridotite likely represents a fragment of subcontinental lithospheric mantle. It experienced early partial fusion and depletion of incompatible elements at moderate pressure in the spinel stability field, followed by transport to high-pressure conditions at $1230{ }^{\circ} \mathrm{C}$ and $50 \mathrm{kbar}$, where the Stage 1 garnet-bearing assemblage was stabilized. Subsequently, the depleted peridotite was metasomatized by transient, primitive basaltic melts, with the addition of $\mathrm{Rb}, \mathrm{Th}, \mathrm{U}, \mathrm{Pb}$, and $\mathrm{Sr}$. Dynamic recrystallization, possibly with a progressive transition to grain size sensitive creep, occurred during Stage 2 at $\sim 915^{\circ} \mathrm{C}$ and $24 \mathrm{kbar}$ in a flattening-dominated, transpressive deformation regime. This event occurred prior to incorporation of the peridotite in granulite and may reflect the early stages of convergence between Brunia and Moldanubia. The static recrystallization and local growth of spinel within kelyphite at $900^{\circ} \mathrm{C}$ and $17-21 \mathrm{kbar}$ (Stage 3) probably took place after entrainment in granulite and was likely isofacial with granulite peak metamorphism.

Keywords: peridotite, LPO, geochemistry, radiogenic isotopes, PT conditions, Moldanubian

Received: 1 July 2009; accepted 3 December 2009; handling editor: J. Konopásek

The online version of this article (doi: 10.3190/jgeosci.052) contains supplementary electronic material.

\section{Introduction}

Fragments of mantle-derived peridotite are a distinctive and widespread feature of convergent orogenic belts around the world, including the Caledonian, Variscan, and Alpine belts in Europe. Although such peridotites are subordinate in volume to surrounding crustal rocks, they commonly provide a wealth of information on properties of the mantle and processes related to incorporation of peridotites into the crust.

The focus of this investigation, the Sklené nad Oslavou peridotite, is a Variscan garnet peridotite boudin enclosed by granulite of the Moldanubian Gföhl Assemblage. Despite its small size $(0.7 \times 1.0 \mathrm{~m})$, the Sklené garnet peridotite deserves detailed examination because of its polymetamorphism, distinctive texture, interesting olivine 
lattice-preferred orientation (LPO), and remarkable lack of serpentinization, features which taken together are different from those commonly exhibited by other Czech garnet peridotites. Some preliminary data on the Sklené mineral and rock compositions were published previously in an overview of Czech garnet peridotites (Medaris et al. 2005), and these data are included here for the sake of completeness and convenience of the reader. In this detailed investigation, we present new data on the mineralogy, petrofabrics, geochemistry (elemental and isotopic), Sm-Nd cooling age, and Re-Os model depletion age of the boudin, followed by an interpretation of its evolution from a mantle source to its eventual incorporation into a crustal milieu.

\section{Geological setting}

\subsection{Peridotites in the Moldanubian Zone}

Numerous bodies of mantle-derived peridotite occur in various tectonostratigraphic units in the Moldanubian Zone of the Bohemian Massif (Fig. 1a), including the Monotonous and Varied groups, the Gföhl Unit and the Kutná Hora-Svratka Terrane, which includes elements of the Gföhl Unit (both shown in green in Fig. 1a), the Teplá-Barrandian block, and the Moravo-Silesian Terrane (Machart 1984). Most of these ultramafic bodies are spinel peridotite and include meta-ophiolite in the Teplá-Barrandian block and Moravo-Silesian Terrane (Cháb 1973; Jelínek et al. 1984; Kastl and Tonika 1984; Beard et al. 1995; Höck et al. 1997; Jelínek et al. 1997). The Gföhl Unit and its correlatives in the Kutná HoraSvratka Terrane, however, are unique in containing garnet peridotite in addition to spinel peridotite. Elsewhere in the European Variscides, garnet peridotite also occurs in the Saxothuringian Zone of the Bohemian Massif (Schmädicke and Evans 1997) and in Moldanubian tectonic units in other Variscan massifs, including the Schwarzwald (Kalt et al. 1995; Kalt and Altherr 1996), Vosges (Altherr and Kalt 1996), and Massif Central (Lasnier 1971; Gardien et al. 1990).

The Gföhl Unit is an assemblage of high-grade orthogneiss, paragneiss, migmatite, felsic kyanite-garnet granulite, and scattered peridotite bodies, and amphibolite occurs at the base of the complex. This lithologic association is thought to have originated in a Devonian back-arc basin related to the subduction of Saxothuringia beneath Teplá-Barrandia and Moldanubia (Carswell 1991; Schulmann et al. 2005). Carboniferous closure of the thermally weakened back-arc basin, due to convergence and eventual collision of Brunia, led to crustal thickening and $\sim 340 \mathrm{Ma}$ high pressure-temperature metamorphism in deeper crustal levels (the Gföhl Assemblage). Metamorphism was followed soon thereafter by rapid exhumation, the evidence for which is the presence of Gföhl detritus in 326 to 345 Ma Viséan sediments of the Culm foreland basin (Hartley and Otava 2001).

Peridotites in the Gföhl Unit display diverse characteristics and have been divided into three groups, based on their texture, mineralogy, elemental and isotopic chemical composition, PT conditions, and calculated cooling rates (Medaris et al. 1990, 2005). Type I, e.g. the Mohelno peridotite, is surrounded by granulite and consists predominantly of $\mathrm{Mg}-\mathrm{Cr}$ spinel peridotite, in which garnet occurs only in the margins of the peridotite body within a few meters of granulite or in closely associated peridotite boudins in granulite. The Mohelno spinel peridotite is devoid of eclogite lenses. Type II has been identified in the Horní Bory quarry and is represented by a group of $\mathrm{Mg}-\mathrm{Cr}$ to $\mathrm{Fe}-\mathrm{Ti}$ spinel-garnet peridotite boudins, associated with abundant garnet pyroxenite, which are enclosed by felsic granulite. Type III, e.g. the Nové Dvory peridotite, is hosted by migmatitic gneiss, consists solely of $\mathrm{Mg}-\mathrm{Cr}$ garnet peridotite, and contains prominent lenses of eclogite. Type I spinel peridotite is interpreted as fragments of suboceanic lithosphere or asthenosphere, and Type III garnet peridotite is most likely derived from subcontinental lithosphere (Medaris et al. 2005). Type II Fe-Ti peridotite has been modelled as the product of reaction between $\mathrm{Mg}-\mathrm{Cr}$ peridotite and percolating, $\mathrm{SiO}_{2}-$ undersaturated basaltic melt in a mantle wedge above a Variscan subduction zone (Ackerman et al. 2009).

\subsubsection{The Sklené peridotite boudin and host granulite}

The Sklené garnet peridotite is a solitary, $0.7 \times 1.0 \mathrm{~m}$ boudin enclosed by felsic granulite (Fiala 1966) of the Bory granulite, which is an $\sim 4 \times 9 \mathrm{~km}$ body surrounded by a variety of high-grade gneisses and migmatites (Fig. 1b). The boudin was previously exposed in a railroad cut, but it is now completely obscured by colluvium and vegetation. The Sklené peridotite and host granulite are likely related to the suite of ultramafic boudins and associated felsic granulite in the Horní Bory quarry (Ackerman et al. 2009), which is located $\sim 2 \mathrm{~km} \mathrm{WSW}$ of the Sklené locality (Fig. 1b). On a regional scale, the Bory granulite and associated gneisses, which are part of the Gföhl Unit, represent the lower levels of orogenically thickened Moldanubian crust and now constitute the uppermost structural level of the Moldanubian Zone (Schulmann et al. 2005, 2009).

The host felsic granulite consists of quartz, plagioclase, alkali feldspar, garnet, and kyanite, and subordinate, more mafic varieties of granulite also contain clinopyroxene and orthopyroxene (Mísař et al. 1984). Retrogression of granulite is widespread, yielding garnet-sillimanite or garnet-biotite-cordierite assemblages (Kotková et al. 2003). The garnet peridotite boudin is separated from 
granulite by a reaction zone $\sim 2 \mathrm{~cm}$ thick, which consists of an inner zone $(\sim 1 \mathrm{~cm})$ predominantly of talc, an intermediate zone $(\sim 3 \mathrm{~mm})$ of talc, anthophyllite, and hornblende, and an outer zone $(\sim 7 \mathrm{~mm})$ of phlogopite. This sequence of minerals resulted from reaction between peridotite and felsic granulite under amphibolite-facies conditions.

\section{Petrography}

\subsection{Texture}

The Sklené peridotite has a pronounced inequigranular texture, in which large, rounded, subequant grains of garnet $(\leq 7 \mathrm{~mm})$ are surrounded by a much finer-grained, extensively recrystallized matrix of olivine, orthopyroxene, clinopyroxene, and subordinate amphibole (Figs 2-4). Additionally, pentlandite, $(\mathrm{Fe}, \mathrm{Ni})_{9} \mathrm{~S}_{8}$, and heazlewoodite, $\mathrm{Ni}_{3} \mathrm{~S}_{2}$, occur as small, irregular grains at silicate boundaries or as rounded blebs within silicates. The matrix consists of subordinate, larger porphyroclastic grains $(\sim 0.5 \mathrm{~mm}$ to $1.0 \mathrm{~mm})$ of olivine and pyroxene, which are surrounded by much finer grained $(\sim 0.1 \mathrm{~mm})$, recrystallized olivine and pyroxene with predominantly straight to gently curved grain boundaries and $120^{\circ}$ triple junctions (Figs $2 \mathrm{~b}, 3 \mathrm{~b}, 4 \mathrm{~b}$, 5 and 6). The porphyroclasts have axial ratios of $<1: 1.5$ and are most commonly randomly oriented. However, it is possible to define a weak foliation and lineation in hand specimen, which we subsequently denote as the fabric reference frame, where $\mathrm{X}$ is parallel to the lineation and $\mathrm{Z}$ is the pole to the foliation. We infer that this reference frame reflects the finite strain ellipsoid within the peridotite. The finer grains have axial ratios of around $1: 2$, decreasing to $<1: 1.5$ at distances greater than $\sim 350 \mu \mathrm{m}$ from the garnet porphyroclasts (Fig. 5). Most of these finer grains have their longest axis parallel to fabric $\mathrm{X}$ and
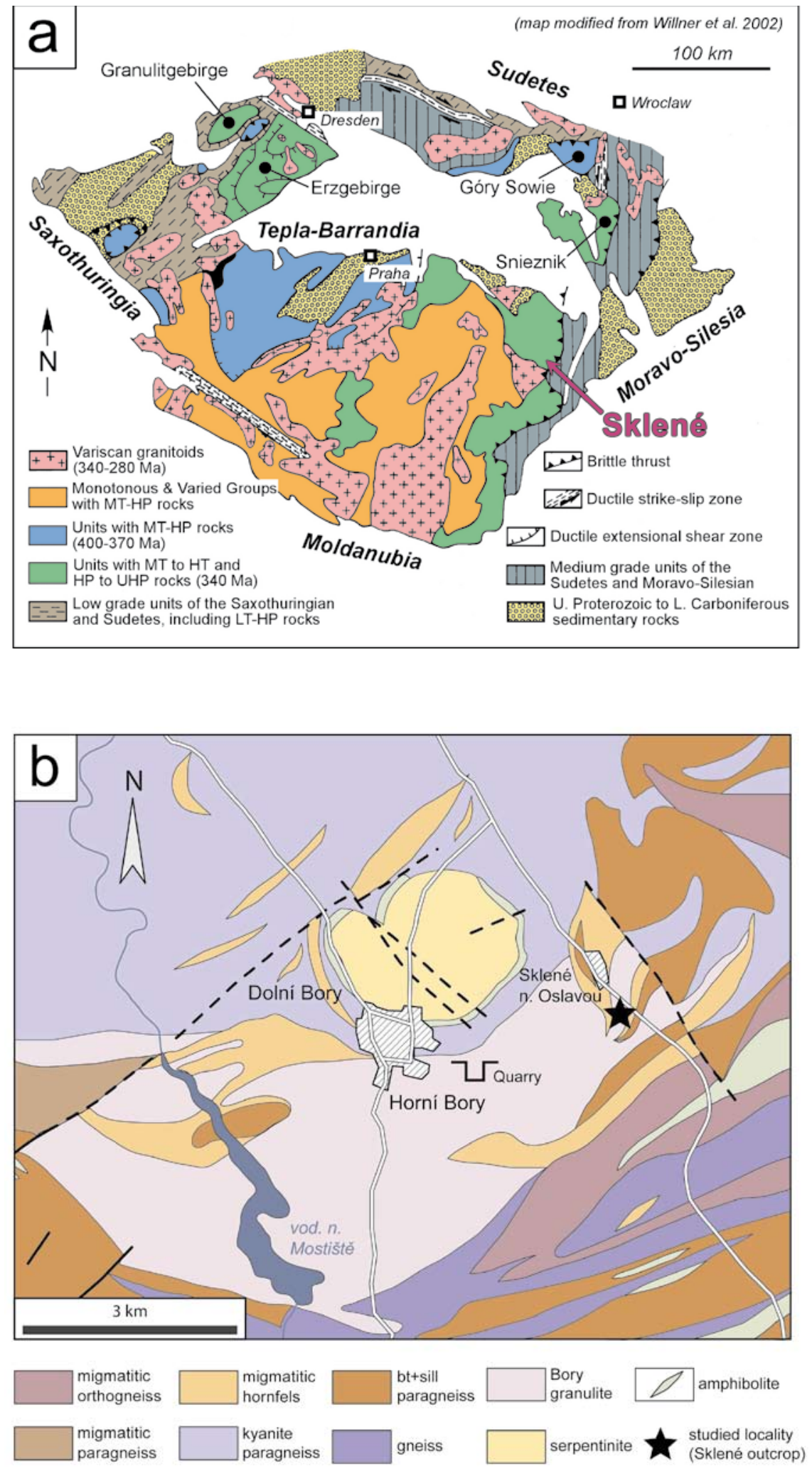

Fig. 1a - Tectonostratigraphic and metamorphic map of the Bohemian Massif, showing the location of the Sklené peridotite (map modified from Willner et al. 2002). The Gföhl and correlative units in Moldanubia are indicated in green; $\mathbf{b}$ - Geological map of the Sklené nad Oslavou peridotite locality, Bory granulite, and surroundings. 

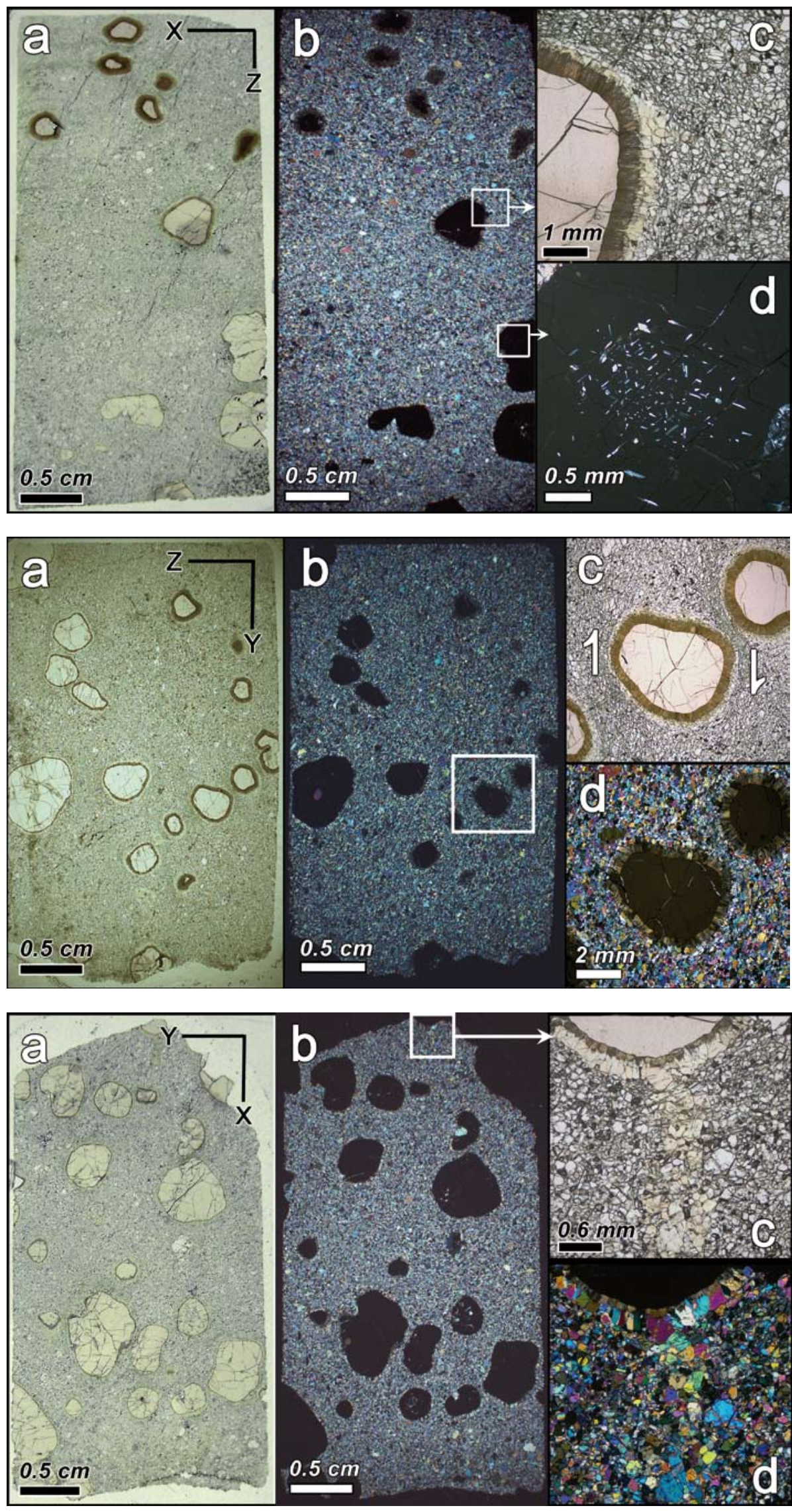

Fig. 2 Photomicrographs of the Sklené garnet peridotite, illustrating large rounded garnet grains in a fine-grained, extensively recrystallized matrix of olivine, orthopyroxene, clinopyroxene, and subordinate pargasitic amphibole. Thin section is cut parallel to the $\mathrm{X}-\mathrm{Z}$ fabric plane. $\mathbf{a}-$ Plane polarized light. b - Crossed polarizers. c - Composite kelyphite rim on garnet. Pre- to syn-kinematic pargasite in pressure shadows has a delta-shape, indicating non-coaxial shear. Plane polarized light. d - Oriented, acicular grains of orthopyroxene and amphibole in garnet. Partly crossed polarizers.

Fig. 3 Photomicrographs of the Sklené garnet peridotite. Thin section is cut parallel to the $\mathrm{Y}-\mathrm{Z}$ fabric plane. a - Plane polarized light. $\mathbf{b}-$ Crossed polarizers. c - Pre- to syn-kinematic pargasite in a sigma-shaped pressure shadow of garnet, indicating non-coaxial shear. Sense of shear indicated by the half arrows. Plane polarized light. d - The same view, crossed polarizers.

Fig. 4 Photomicrographs of the Sklené garnet peridotite. Thin section is cut parallel to the $\mathrm{X}-\mathrm{Y}$ fabric plane. a - Plane polarized light. b - Crossed polarizers. c - Composite kelyphite rim on garnet; note the train of pre- to syn-kinematic pale brownish pargasite grains extending from the kelyphite into the matrix. Plane polarized light. d - The same view, crossed polarizers. 


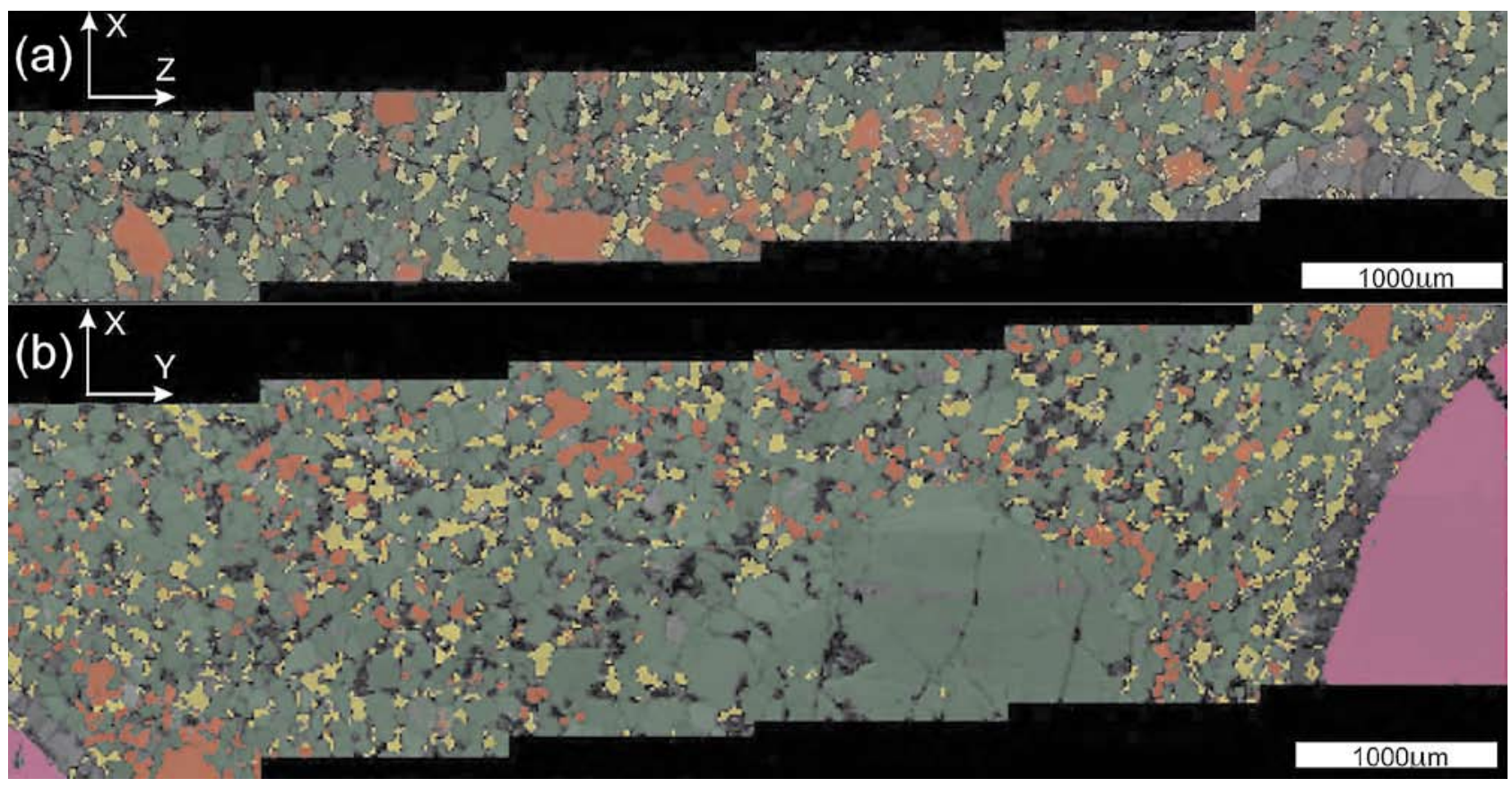

Fig. 5 Electron back-scattered diffraction (EBSD) maps of recrystallized matrix of Sklené peridotite. $\mathbf{a}-$ Thin section cut parallel to the X-Z fabric plane. $\mathbf{b}$ - Thin section cut parallel to the X-Y fabric plane. Grains are coloured according to phase (red = clinopyroxene; yellow = orthopyroxene; green $=$ olivine; purple $=$ garnet). Colours are overlain on band contrast map, allowing grain shapes to be resolved. Amphibole (pargasite) was not indexed, so is indicated in grey. Foliations, defined by grain shape fabrics, intensify within $350 \mu \mathrm{m}$ of garnet porphyroclasts towards the right hand side of both images. A large olivine porphyroclast near the centre of $\mathbf{b}$ contains subgrains that are elongate parallel to fabric direction $\mathrm{Y}$ (indicated by variation in grey shade due to variation in band contrast).

their shortest axis parallel to fabric Z. Within $350 \mu \mathrm{m}$ of the garnet porphyroclasts, the fine grains are inclined to the main foliation of the rock (the $\mathrm{X}-\mathrm{Y}$ plane), and these local foliations wrap around the porphyroclasts (Fig. 5), where they exhibit sigma-shaped pressure shadows (Fig. $3 \mathrm{c}$ ). Using the linear intercept method (Smith and Guttman 1953) in $\mathrm{X}-\mathrm{Z}$ sections, we estimate that the grain size is approximately $40 \mu \mathrm{m}$, which can be corrected to a 3-dimensional grain size by multiplication by a factor of 1.75 (e.g. van der Wal et al. 1993), yielding an estimated average recrystallized grain size of $70 \mu \mathrm{m}$.

Garnet grains are surrounded by thin rims of kelyphite, which consist of an outer zone of monomineralic pargasitic amphibole and an inner zone of extremely fine-grained, intergrown spinel and orthopyroxene (Fig. 7). The inner kelyphite zone is confined to the margins of garnet, but the kelyphitic amphibole is drawn out into the matrix, parallel to the X fabric direction (Figs $2 \mathrm{c}$ and $4 \mathrm{c}$ ), and some kelyphitic tails define a delta geometry (Figs 2c, $4 c)$. Small amounts of very fine-grained amphibole are also dispersed in the recrystallized matrix. Significantly, spinel and garnet are absent from the matrix.

Individual grains of olivine, orthopyroxene, or clinopyroxene occur rarely as inclusions in garnet, as seen in Fig. 4b. Some, but not all, garnet grains contain clusters of tiny, oriented, acicular grains of orthopyroxene and amphibole (Fig. 2d). Such clusters are not uniformly dis- tributed within garnet grains, but occur instead in small domains near grain margins.

\subsection{Mineral compositions}

Minerals in the Sklené peridotite are typical of those in other mantle-derived $\mathrm{Mg}-\mathrm{Cr}$ garnet peridotites, including Mg-rich olivine and orthopyroxene, Cr-diopside, and pyrope-rich garnet. Compositions of the constituent minerals were determined by electron probe microanalysis, the analytical details of which are given in the Appendix. Because of the large uncertainty in calculating $\mathrm{Fe}^{2+}$ and $\mathrm{Fe}^{3+}$ by stoichiometry in silicate minerals with low $\mathrm{Fe} / \mathrm{Mg}$ ratios, as is the case here, all $\mathrm{Fe}$ has been taken as $\mathrm{FeO}$, which is a convention commonly followed in studies of $\mathrm{Mg}-\mathrm{Cr}$ peridotites.

The composition of olivine is relatively uniform on both the intragrain and intergrain scales. Olivine porphyroclasts (Table 1) have a mean $\mathrm{Mg} \#[100 \times \mathrm{Mg} /(\mathrm{Mg}+\mathrm{Fe})]$ of 89.5 and contain 0.40 wt. \% NiO.

Garnet (Table 2) is relatively uniform in composition, except within $\sim 25$ micrometers of grain margins, where there is a marked decrease in $\mathrm{Mg} \#$ from 81.5 to 74.7 (illustrated by the bright band at the garnet margin in Fig. 7b). Garnet is pyrope-rich, and the molar proportions of almandine : spessartine : pyrope : grossular vary little from the cores, $16.3: 0.6: 73.3: 9.9$, to intermediate 


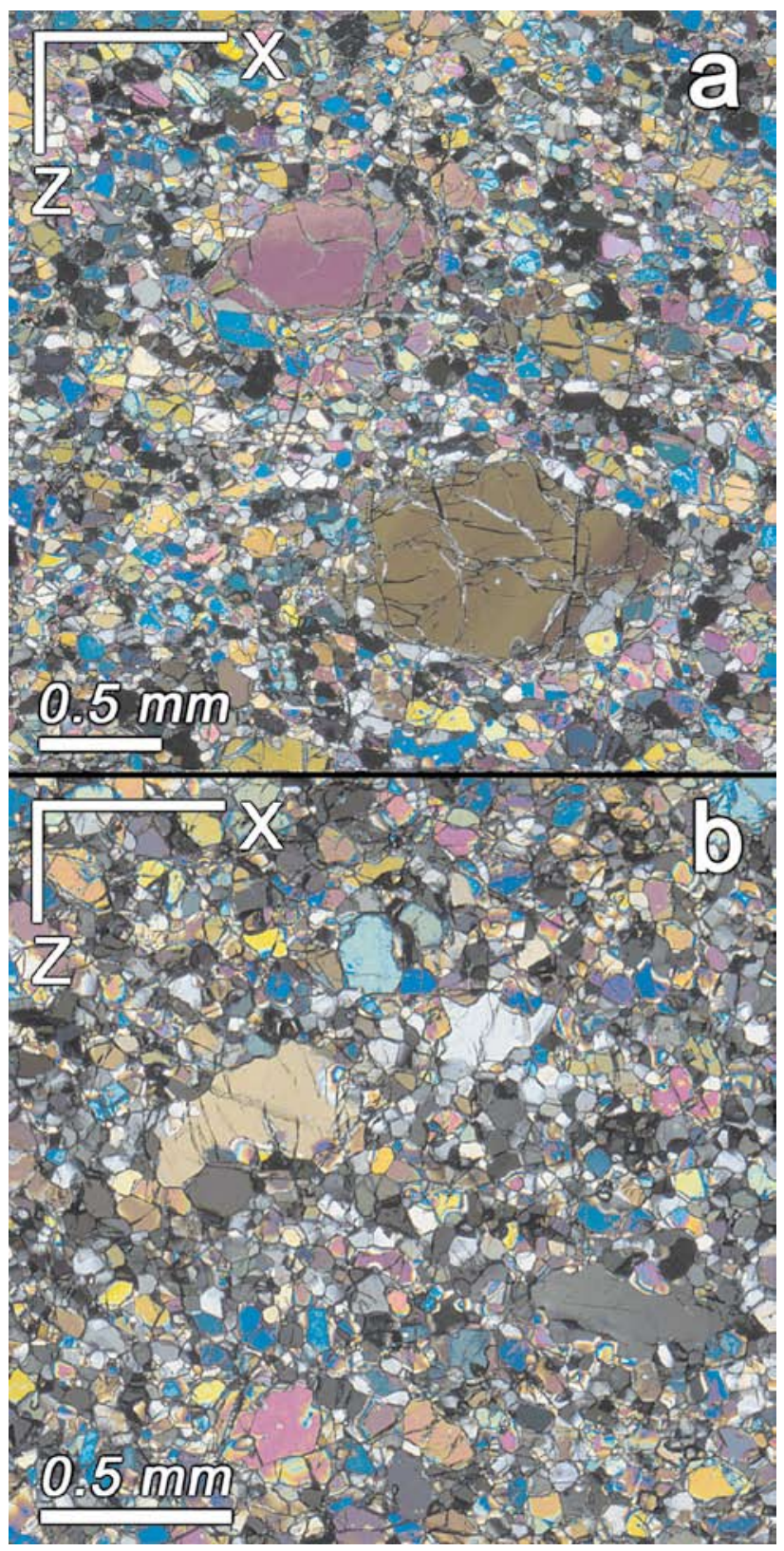

Fig. 6 Photomicrographs of the recrystallized matrix in the Sklené peridotite. Thin section is cut parallel to the $\mathrm{X}-\mathrm{Z}$ fabric plane; crossed polarizers. a - Two relatively coarse, porphyroclastic olivine grains in the recrystallized matrix. b-Several relatively coarse, porphyroclastic orthopyroxene grains in the recrystallized matrix.

zones, $16.6: 0.6: 72.9: 9.9$, of the large grains. Garnet contains $\sim 0.9$ wt. $\% \mathrm{Cr}_{2} \mathrm{O}_{3}$, except for the cores of a few grains, where $\mathrm{Cr}_{2} \mathrm{O}_{3}$ reaches 2.2 wt. \%, and $\mathrm{Mg \#}$ attains a maximum value of 82.1 .

The composition of orthopyroxene (Table 3 ) is similar for most elements among the cores of larger grains, their rims, and matrix grains, all having a Mg\# of 90.6-90.8 and $\mathrm{CaO}$ contents of $0.35-0.37$ wt. \%. However, there is a slight, but significant, increase in $\mathrm{Al}_{2} \mathrm{O}_{3}$ from the cores of larger grains, $1.02 \mathrm{wt}$. $\%$, to rims, $1.24 \mathrm{wt}$. $\%$, to matrix

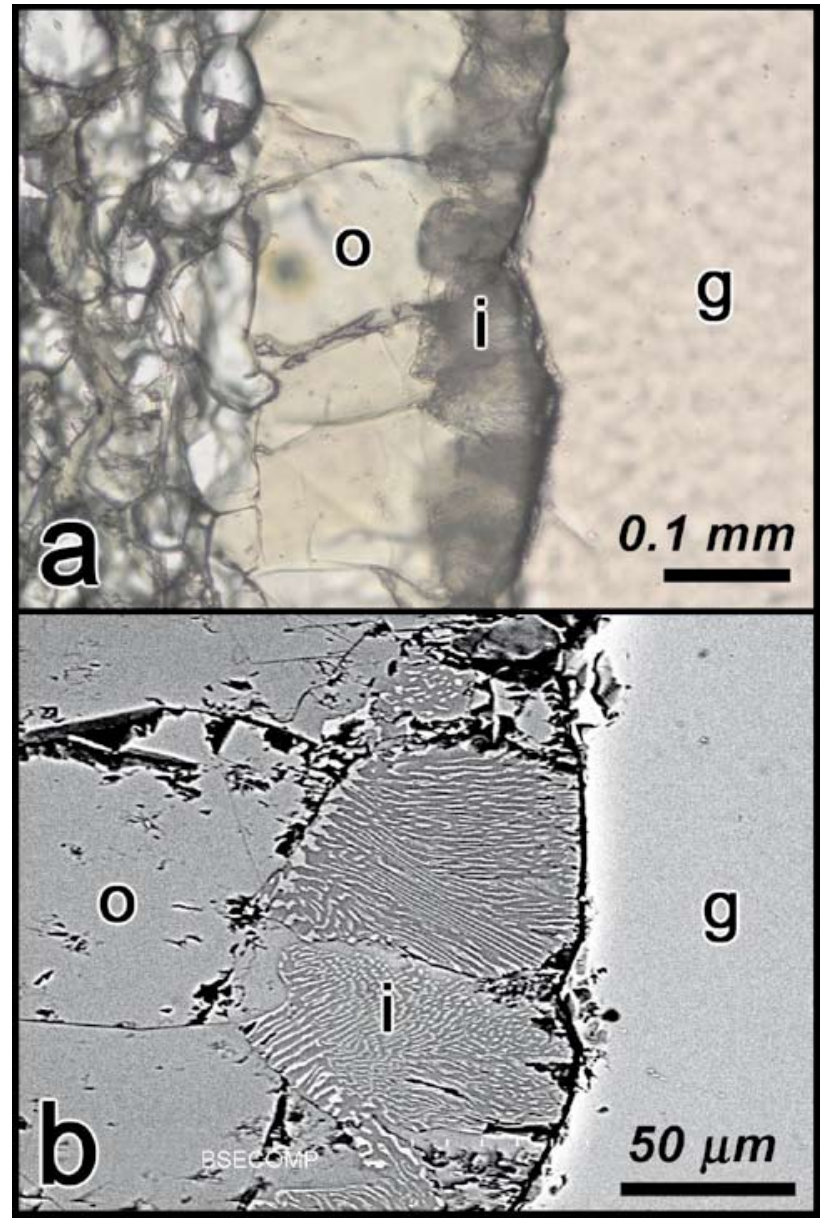

Fig. 7a - Photomicrograph of composite kelyphite around garnet. Abbreviations: g, garnet; i, inner kelyphite (spinel + orthopyroxene); o, outer kelyphite (pargasite). Crossed polarizers; b - Back-scattered electron (BSE) image of kelyphite, illustrating the extremely fine-grained intergrowth of spinel (light gray) and orthopyroxene (dark gray) in the inner kelyphite.

grains, 1.45 wt. $\%$, which is accompanied by an increase in $\mathrm{Cr}_{2} \mathrm{O}_{3}$ from 0.10 to 0.14 to 0.17 wt. \%. Compared to exterior grains, the tiny, acicular grains of orthopyroxene in garnet (Fig. 2d) have a higher $\mathrm{Mg \# ,} \mathrm{92.3,} \mathrm{and} \mathrm{ap-}$ parently higher $\mathrm{Al}_{2} \mathrm{O}_{3}$ content, $3.3 \mathrm{wt}$. \%, reflecting the chemical influence of the enclosing garnet, i.e., exchange of $\mathrm{Fe}$ and $\mathrm{Mg}$ between orthopyroxene and garnet during cooling in the former parameter and fluorescence effects of surrounding garnet in the latter.

The compositional variation in clinopyroxene (Table 3 ) is similar to that in orthopyroxene. The cores and rims of larger grains and matrix grains have comparable $\mathrm{Mg \#}$ numbers, 92.0-92.6, and $\mathrm{CaO}$ contents, 20.27-20.43 wt. \%, whereas $\mathrm{Al}_{2} \mathrm{O}_{3}$ increases from the cores of larger grains to rims to matrix grains, from 3.62 to 3.84 to 4.00 wt. $\%$, as does $\mathrm{Cr}_{2} \mathrm{O}_{3}$, from 0.64 to 0.80 to 0.81 wt. $\%$.

Amphibole (Table 4) in kelyphite is pargasite, with 6.3 atoms of Si per formula unit, 1.66 atoms of $\mathrm{Ca}$ in the B- 
Tab. 1 Electron microprobe analysis: olivine porphyroclasts

\begin{tabular}{lcc}
\hline & mean & 1 S.D.** \\
wt. \% & $n^{* *}=13$ & \\
\hline $\mathrm{SiO}_{2}$ & 40.58 & 0.25 \\
$\mathrm{FeO}^{*}$ & 10.19 & 0.11 \\
$\mathrm{MnO}$ & 0.11 & 0.01 \\
$\mathrm{MgO}$ & 48.78 & 0.22 \\
$\mathrm{NiO}$ & 0.40 & 0.02 \\
\hline $\mathrm{Sum}$ & 100.06 & \\
\hline cations per 4 oxygen atoms & \\
$\mathrm{Si}$ & 0.997 & 0.003 \\
$\mathrm{Fe}$ & 0.209 & 0.001 \\
$\mathrm{Mn}$ & 0.002 & 0.000 \\
$\mathrm{Mg}$ & 1.787 & 0.006 \\
$\mathrm{Ni}$ & 0.008 & 0.000 \\
\hline Sum & 3.003 & \\
\hline $\mathrm{Mg} \#$ & 89.5 & 0.1 \\
$*$ Total Fe as FeO & \\
$* * \mathrm{n}-$ number of analyses; & \\
S.D. - standard deviation
\end{tabular}

Tab. 2 Electron microprobe analyses of garnet

\begin{tabular}{|c|c|c|c|c|}
\hline & $\begin{array}{c}\text { cores } \\
\text { hi-Cr** }\end{array}$ & $\begin{array}{c}\text { cores } \\
\text { lo-Cr** }\end{array}$ & intermediate & rims \\
\hline wt. \% & $\mathrm{n}=3$ & $\mathrm{n}=3$ & $n=6$ & $\mathrm{n}=2$ \\
\hline $\mathrm{SiO}_{2}$ & 42.00 & 42.48 & 42.27 & 41.67 \\
\hline $\mathrm{TiO}_{2}$ & 0.62 & 0.52 & 0.54 & 0.36 \\
\hline $\mathrm{Al}_{2} \mathrm{O}_{3}$ & 21.03 & 22.30 & 22.26 & 22.47 \\
\hline $\mathrm{Cr}_{2} \mathrm{O}_{3}$ & 2.21 & 0.91 & 0.90 & 1.07 \\
\hline $\mathrm{FeO}^{*}$ & 8.22 & 8.53 & 8.63 & 11.41 \\
\hline $\mathrm{MnO}$ & 0.26 & 0.31 & 0.31 & 0.63 \\
\hline $\mathrm{MgO}$ & 21.14 & 21.50 & 21.31 & 18.86 \\
\hline $\mathrm{CaO}$ & 4.46 & 4.02 & 4.02 & 4.04 \\
\hline Sum & 99.94 & 100.57 & 100.24 & 100.51 \\
\hline \multicolumn{5}{|c|}{ cations per 12 oxygen atoms } \\
\hline $\mathrm{Si}$ & 2.998 & 2.999 & 2.996 & 2.987 \\
\hline $\mathrm{Ti}$ & 0.033 & 0.028 & 0.029 & 0.019 \\
\hline $\mathrm{Al}$ & 1.769 & 1.855 & 1.859 & 1.898 \\
\hline $\mathrm{Cr}$ & 0.125 & 0.051 & 0.050 & 0.061 \\
\hline $\mathrm{Fe}$ & 0.491 & 0.503 & 0.512 & 0.684 \\
\hline $\mathrm{Mn}$ & 0.016 & 0.018 & 0.019 & 0.038 \\
\hline $\mathrm{Mg}$ & 2.250 & 2.262 & 2.251 & 2.015 \\
\hline $\mathrm{Ca}$ & 0.341 & 0.304 & 0.305 & 0.311 \\
\hline Sum & 8.022 & 8.021 & 8.021 & 8.014 \\
\hline$\%$ Alm** & 15.8 & 16.3 & 16.6 & 22.4 \\
\hline$\%$ Sps** & 0.5 & 0.6 & 0.6 & 1.3 \\
\hline$\% \operatorname{Prp} * *$ & 72.6 & 73.3 & 72.9 & 66.1 \\
\hline$\%$ Grs** & 11.0 & 9.9 & 9.9 & 10.2 \\
\hline $\mathrm{Mg} \#$ & 82.1 & 81.8 & 81.5 & 74.7 \\
\hline \multicolumn{5}{|c|}{ * Total $\mathrm{Fe}$ as $\mathrm{FeO}$} \\
\hline \multicolumn{5}{|c|}{$\begin{array}{l}\text { ** hi-Cr - high chromium; lo-Cr - low chromium; } \\
\text { Alm - almandine; Sps - spessartine; Prp - pyrope; } \\
\text { Grs - grossular }\end{array}$} \\
\hline
\end{tabular}

site, 0.58 atoms of $\mathrm{Na}+\mathrm{K}$ in the $\mathrm{A}$-site, and an $\mathrm{Mg \#}$ of 90.0. The scarce amphibole in the matrix is also pargasitic, but with a slightly lower $\mathrm{Al}_{2} \mathrm{O}_{3}$ content, 12.45 wt. \%, higher $\mathrm{CaO}$ content, 11.52 wt. \%, and higher $\mathrm{Mg \# ,} \mathrm{91.5.}$ The tiny, acicular grains of amphibole in garnet (Fig. 2d) are also pargasitic, but with slightly higher $\mathrm{Al}_{2} \mathrm{O}_{3}, 17.07$ wt. \%, and $\mathrm{Mg \# ,} \mathrm{92.8,} \mathrm{compared} \mathrm{to} \mathrm{exterior} \mathrm{amphibole,}$ which reflects the chemical influence of encasing garnet, as also observed for orthopyroxene.

Spinel (Table 4), as noted above, occurs only as an extremely fine-grained intergrowth with orthopyroxene in inner kelyphite rims (Fig. 5). The spinel is Mg-rich and Cr-poor, having a $\mathrm{Mg \#}$ of 72 and a $\mathrm{Cr} \#[100 \times \mathrm{Cr} /$ $(\mathrm{Cr}+\mathrm{Al})]$ of 11 . Such a composition is typical of spinel, which occurs in kelyphite in garnet peridotites and has formed through the reaction, garnet + olivine $\rightarrow$ spinel + orthopyroxene.

\subsection{Mode}

The modal composition of the Sklené peridotite was calculated by a linear least squares method (Wright and Doherty 1970), utilizing its constituent mineral compositions (Tables 1-3) and bulk rock composition (Table 5). Ignoring the small amounts of pargasite and spinel in the sample, the Sklené peridotite is a lherzolite, which contains $55 \%$ olivine, $13 \%$ garnet, $22 \%$ orthopyroxene, and $10 \%$ clinopyroxene.

\section{Petrofabrics}

The petrofabrics (lattice-preferred orientation, LPO) and microstructures of olivine, orthopyroxene and clinopyroxene in the matrix of the Sklené peridotite were characterized using electron backscatter diffraction, as described in the Appendix. Representative microstructural maps and all measured LPOs are illustrated in Figs 5 and 8. Crystallographic orientations of both porphyroclasts and recrystallized grains are included in these diagrams, but since the latter are volumetrically dominant and only one point per grain is represented on the fabric diagrams, the fine grains contribute the majority of data to the measured petrofabrics.

The LPOs of pyroxenes and olivine were measured in two thin sections, in the $\mathrm{X}-\mathrm{Z}$ and $\mathrm{X}-\mathrm{Y}$ fabric planes. The resulting LPOs of all phases are relatively weak, reflected in M-indices (Skemer et al. 2005) $<0.1$ and maximum m.u.d. (multiples of uniform density) $<3$. In both pyroxenes, where there is a resolvable LPO, the normals to (100) in clinopyroxene and [100] in orthopyroxene are randomly distributed, both phases have axial concentrations of [010] about the $\mathrm{Z}$ fabric axis, and [001] are distributed in weak girdles in the $\mathrm{X}-\mathrm{Y}$ fabric plane (Fig. 8b, d). Olivine has girdles of [100] and [001] in 
Tab. 3 Electron microprobe analyses of pyroxene

\begin{tabular}{|c|c|c|c|c|c|c|c|}
\hline & \multicolumn{4}{|c|}{ Orthopyroxene } & \multicolumn{3}{|c|}{ Clinopyroxene } \\
\hline & p.clast** & p.clast & matrix & lamellae & p.clast & p.clast & matrix \\
\hline & & rims & grains & & & rims & \\
\hline wt. \% & $\mathrm{n}=3$ & $\mathrm{n}=2$ & $\mathrm{n}=9$ & $\mathrm{n}=8$ & $\mathrm{n}=3$ & $\mathrm{n}=2$ & $\mathrm{n}=10$ \\
\hline $\mathrm{SiO}_{2}$ & 56.93 & 56.73 & 56.64 & 55.83 & 54.95 & 54.37 & 54.25 \\
\hline $\mathrm{TiO}_{2}$ & 0.11 & 0.05 & 0.07 & 0.06 & 0.30 & 0.32 & 0.30 \\
\hline $\mathrm{Al}_{2} \mathrm{O}_{3}$ & 1.02 & 1.24 & 1.45 & 3.32 & 3.62 & 3.84 & 4.00 \\
\hline $\mathrm{Cr}_{2} \mathrm{O}_{3}$ & 0.10 & 0.14 & 0.17 & 0.12 & 0.64 & 0.80 & 0.81 \\
\hline $\mathrm{FeO}^{*}$ & 6.34 & 6.44 & 6.43 & 5.28 & 2.47 & 2.28 & 2.40 \\
\hline $\mathrm{MnO}$ & 0.09 & 0.11 & 0.11 & 0.04 & 0.06 & 0.06 & 0.08 \\
\hline $\mathrm{MgO}$ & 35.20 & 34.97 & 34.87 & 35.53 & 15.99 & 15.92 & 15.97 \\
\hline $\mathrm{CaO}$ & 0.36 & 0.35 & 0.37 & 0.25 & 20.33 & 20.43 & 20.27 \\
\hline $\mathrm{Na}_{2} \mathrm{O}$ & 0.02 & 0.01 & 0.02 & 0.01 & 1.81 & 1.89 & 1.86 \\
\hline Sum & 100.17 & 100.03 & 100.14 & 100.45 & 100.17 & 99.90 & 99.94 \\
\hline \multicolumn{8}{|c|}{ cations per 6 oxygen atoms } \\
\hline $\mathrm{Si}$ & 1.961 & 1.958 & 1.953 & 1.909 & 1.974 & 1.961 & 1.956 \\
\hline $\mathrm{Ti}$ & 0.003 & 0.001 & 0.002 & 0.001 & 0.008 & 0.009 & 0.008 \\
\hline $\mathrm{Al}$ & 0.041 & 0.050 & 0.059 & 0.134 & 0.153 & 0.163 & 0.170 \\
\hline $\mathrm{Cr}$ & 0.003 & 0.004 & 0.004 & 0.003 & 0.018 & 0.023 & 0.023 \\
\hline $\mathrm{Fe}$ & 0.183 & 0.186 & 0.186 & 0.151 & 0.074 & 0.069 & 0.072 \\
\hline $\mathrm{Mn}$ & 0.003 & 0.003 & 0.003 & 0.001 & 0.002 & 0.002 & 0.002 \\
\hline $\mathrm{Mg}$ & 1.807 & 1.799 & 1.792 & 1.811 & 0.856 & 0.856 & 0.859 \\
\hline $\mathrm{Ca}$ & 0.013 & 0.013 & 0.014 & 0.009 & 0.782 & 0.790 & 0.783 \\
\hline $\mathrm{Na}$ & 0.001 & 0.000 & 0.001 & 0.001 & 0.126 & 0.132 & 0.130 \\
\hline Sum & 4.015 & 4.014 & 4.014 & 4.021 & 3.995 & 4.004 & 4.004 \\
\hline $\mathrm{Ca}$ & 0.7 & 0.6 & 0.7 & 0.5 & 45.7 & 46.1 & 45.7 \\
\hline $\mathrm{Mg}$ & 90.2 & 90.1 & 90.0 & 91.9 & 50.0 & 49.9 & 50.1 \\
\hline $\mathrm{Fe}$ & 9.1 & 9.3 & 9.3 & 7.7 & 4.3 & 4.0 & 4.2 \\
\hline $\mathrm{Mg} \#$ & 90.8 & 90.6 & 90.6 & 92.3 & 92.0 & 92.6 & 92.2 \\
\hline
\end{tabular}

the $\mathrm{X}-\mathrm{Y}$ fabric plane and axial concentrations of [010] parallel to the $\mathrm{Z}$ fabric axis (Fig. 8e-f).

\section{Geochemistry}

Major and minor elements in the Sklené peridotite were determined by wet chemical analysis, and trace elements in whole-rock and mineral separates (clinopyroxene and garnet) were obtained by Inductively Coupled Plasma Mass Spectrometry (ICP-MS). The $\mathrm{Sr}$ and Nd isotopes were measured by Thermal Ionization Mass Spectrometry (TIMS). Rhenium, Ir, Ru, Pt, and Pd were analyzed using multi-collector ICP-MS, with concentrations determined by isotopic dilution. Osmium concentrations and isotopic composition were measured by Negative Thermal Ionization Mass Spectrometry (N-TIMS). Details for each of these analytical techniques are given in the Appendix.

\subsection{Major and minor elements}

Consistent with its lherzolitic mode, the Sklené peridotite has a modest concentration of $\mathrm{MgO}, 37.7$ wt. \%, and is only slightly depleted in incompatible major and minor elements, containing 3.31 wt. $\% \mathrm{Al}_{2} \mathrm{O}_{3}, 0.18 \mathrm{TiO}_{2}$, $2.74 \mathrm{CaO}$, and $0.27 \mathrm{Na}_{2} \mathrm{O}$ (Table 5). In oxide variation diagrams (Fig. 9) the Sklené sample plots closer to the composition of primitive mantle (McDonough and Sun 1995) than do most analyzed Czech peridotites, which display a pronounced depletion trend. Although the Sklené peridotite is located geographically closest to the Type II peridotite suite in the Horní Bory quarry, its major-element composition lies between the major element compositional fields for Type I and Type III peridotites (Fig. 9).

\subsection{Trace elements}

\subsubsection{Whole rock}

The rare earth element (REE) contents of the Sklené peridotite are depleted with respect to primitive mantle (McDonough and Sun 1995), with normalized values ranging from $\sim 0.3$ to 0.8 (Fig. 10a, Table 5). The light REE (LREE) are slightly depleted compared to the 
Tab. 4 Electron microprobe analyses of amphibole and spinel

\begin{tabular}{|c|c|c|c|c|c|c|}
\hline & \multicolumn{3}{|c|}{ Amphibole } & \multicolumn{3}{|c|}{ Spinel } \\
\hline & \multirow{2}{*}{$\begin{array}{c}\text { lamellae } \\
\text { in Grt }\end{array}$} & \multirow[t]{2}{*}{ kelyphite } & \multirow[t]{2}{*}{ matrix } & \multicolumn{3}{|c|}{ kelyphite } \\
\hline & & & & & mean & 1 S.D. \\
\hline wt. \% & $\mathrm{n}=8$ & $\mathrm{n}=5$ & $\mathrm{n}=3$ & \multicolumn{3}{|c|}{$\mathrm{n}=7$} \\
\hline $\mathrm{SiO}_{2}$ & 43.83 & 44.35 & 45.82 & \multicolumn{3}{|l|}{ wt. $\%$} \\
\hline $\mathrm{TiO}_{2}$ & 1.56 & 0.94 & 1.61 & $\mathrm{TiO}_{2}$ & 0.02 & 0.01 \\
\hline $\mathrm{Al}_{2} \mathrm{O}_{3}$ & 17.07 & 15.03 & 12.45 & $\mathrm{Al}_{2} \mathrm{O}_{3}$ & 56.42 & 2.54 \\
\hline $\mathrm{Cr}_{2} \mathrm{O}_{3}$ & 0.66 & 0.82 & 0.77 & $\mathrm{Cr}_{2} \mathrm{O}_{3}$ & 10.73 & 2.24 \\
\hline $\mathrm{FeO}^{*}$ & 2.46 & 3.60 & 3.12 & $\mathrm{FeO}^{*}$ & 12.25 & 0.81 \\
\hline $\mathrm{MnO}$ & 0.03 & 0.12 & 0.02 & $\mathrm{MnO}$ & 0.15 & 0.02 \\
\hline $\mathrm{MgO}$ & 17.73 & 18.08 & 18.78 & $\mathrm{MgO}$ & 17.98 & 0.81 \\
\hline $\mathrm{CaO}$ & 10.71 & 10.96 & 11.52 & Sum & 97.55 & \\
\hline $\mathrm{Na}_{2} \mathrm{O}$ & 3.50 & 3.12 & 3.11 & \multicolumn{3}{|c|}{ cations per 4 oxygen atoms } \\
\hline $\mathrm{K}_{2} \mathrm{O}$ & 0.27 & 0.36 & 0.81 & $\mathrm{Ti}$ & 0.000 & 0.000 \\
\hline Sum & 97.82 & 97.38 & 97.81 & $\mathrm{Al}$ & 1.777 & 0.052 \\
\hline \multicolumn{4}{|c|}{ cations per 23 oxygen atoms } & $\mathrm{Cr}$ & 0.227 & 0.051 \\
\hline $\mathrm{Si}$ & 6.127 & 6.269 & 6.434 & $\mathrm{Fe}$ & 0.274 & 0.022 \\
\hline $\mathrm{Ti}$ & 0.164 & 0.100 & 0.171 & $\mathrm{Mn}$ & 0.003 & 0.001 \\
\hline $\mathrm{Al}$ & 2.813 & 2.504 & 2.069 & $\mathrm{Mg}$ & 0.716 & 0.021 \\
\hline $\mathrm{Cr}$ & 0.073 & 0.092 & 0.086 & Sum & 2.998 & \\
\hline $\mathrm{Fe}$ & 0.288 & 0.426 & 0.368 & Mg\# & 71.9 & 2.1 \\
\hline $\mathrm{Mn}$ & 0.004 & 0.014 & 0.002 & $\mathrm{Cr} \#$ & 11.3 & 2.6 \\
\hline $\mathrm{Mg}$ & 3.695 & 3.810 & 3.948 & & & \\
\hline $\mathrm{Ca}$ & 1.604 & 1.660 & 1.741 & & & \\
\hline $\mathrm{Na}$ & 0.949 & 0.855 & 0.850 & & & \\
\hline $\mathrm{K}$ & 0.048 & 0.065 & 0.146 & & & \\
\hline Sum & 15.764 & 15.794 & 15.816 & & & \\
\hline Mg\# & 92.8 & 90.0 & 91.5 & & & \\
\hline
\end{tabular}

heavy REE (HREE), with a $\mathrm{La}_{\mathrm{N}} / \mathrm{Yb}_{\mathrm{N}}$ ratio of 0.71 , but the most distinctive feature of the normalized REE pattern is its pronounced convex upward shape, reflecting the relatively higher normalized values of the middle REE (Fig. 10a). The REE patterns may be compared in a plot of $\mathrm{Ce}_{\mathrm{N}} / \mathrm{Sm}_{\mathrm{N}}$ vs. $\mathrm{Sm}_{\mathrm{N}} / \mathrm{Yb}_{\mathrm{N}}$ (Fig. 11), in which different configurations of REE patterns are separated into four fields, i.e. LREE depleted, LREE enriched, convex upward, and convex downward. Among Czech garnet peridotites, Type II-Fe peridotites, which display convex upward REE patterns, are the group most similar to the Sklené sample with respect to REE pattern, although one sample of Type III peridotite plots close to the Sklené sample.

In a plot of normalized, extended trace elements, the Sklené peridotite exhibits pronounced positive anomalies for $\mathrm{Sr}$ and $\mathrm{U}$ and elevated values for $\mathrm{Rb}$ and Th (Fig. 10b). Such features also occur in Type II-Mg peridotites (Fig. 10b) and in Type II-Fe peridotites (not figured). However, numerous samples of Type II-Mg and -Fe peridotites exhibit negative anomalies for $\mathrm{Zr}$ and $\mathrm{Hf}$, which are not seen in the Sklené sample.

\subsubsection{Clinopyroxene and garnet}

The normalized REE patterns for clinopyroxene and garnet are typical for those in garnet lherzolite, i.e., LREE enriched and slightly convex upward in clinopyroxene, and HREE enriched and LREE depleted in garnet, reflecting the preferential accommodation of LREE in clinopyroxene and HREE in garnet (Fig. 12a, Table 5). The present REE compositions of the Sklené garnet and clinopyroxene most likely represent high-temperature, subsolidus re-equilibration between the two phases, rather than their original compositions resulting from partial fusion and melt extraction. Compared to clinopyroxene in Type II-Mg peridotite, the Sklené clinopyroxene has a slightly higher $\mathrm{Ce}_{\mathrm{N}} / \mathrm{Yb}_{\mathrm{N}}$ ratio, i.e., 6.8 vs. 3.8 (Fig. 12a).

With respect to normalized, extended trace elements, the Sklené clinopyroxene exhibits a pronounced negative $\mathrm{Nb}$ anomaly, a marked positive $\mathrm{Pb}$ anomaly, and slight negative anomalies for Zr, Hf, and Ti (Fig. 12b). Similar anomalies also occur in clinopyroxene from Type IIMg peridotite (Fig. 12b). The Sklené garnet also shows 
Tab. 5 Major-element composition of the Sklené garnet lherzolite and trace-element compositions of rock, clinopyroxene, and garnet

\begin{tabular}{|c|c|c|c|c|c|}
\hline wt. \% & rock & ppm & rock & $\mathrm{cpx}$ & grt \\
\hline $\mathrm{SiO}_{2}$ & 44.36 & $\mathrm{Rb}$ & 0.40 & 0.08 & 0.18 \\
\hline $\mathrm{TiO}_{2}$ & 0.18 & $\mathrm{Sr}$ & 29 & 220 & 1 \\
\hline $\mathrm{Al}_{2} \mathrm{O}_{3}$ & 3.31 & $\mathrm{Y}$ & 2.50 & 3.15 & 13.25 \\
\hline $\mathrm{Cr}_{2} \mathrm{O}_{3}$ & 0.46 & $\mathrm{Zr}$ & 6.58 & 12.25 & 22.84 \\
\hline $\mathrm{NiO}$ & 0.30 & $\mathrm{Nb}$ & 0.20 & 0.07 & 0.23 \\
\hline $\mathrm{FeO}^{*}$ & 8.93 & $\mathrm{Cs}$ & 0.03 & 0.07 & 0.01 \\
\hline $\mathrm{MnO}$ & 0.13 & $\mathrm{Ba}$ & 20 & 0.25 & 1.65 \\
\hline $\mathrm{MgO}$ & 37.70 & $\mathrm{La}$ & 0.225 & 1.78 & 0.03 \\
\hline $\mathrm{CaO}$ & 2.74 & $\mathrm{Ce}$ & 0.669 & 5.46 & 0.10 \\
\hline $\mathrm{Na}_{2} \mathrm{O}$ & 0.27 & $\mathrm{Pr}$ & 0.122 & 1.01 & 0.05 \\
\hline $\mathrm{K}_{2} \mathrm{O}$ & 0.02 & $\mathrm{Nd}$ & 0.761 & 5.51 & 0.60 \\
\hline $\mathrm{P}_{2} \mathrm{O}_{5}$ & 0.05 & $\mathrm{Sm}$ & 0.286 & 1.69 & 0.65 \\
\hline LOI** & 1.67 & $\mathrm{Eu}$ & 0.126 & 0.59 & 0.42 \\
\hline \multirow[t]{2}{*}{ Total } & 100.12 & $\mathrm{Gd}$ & 0.418 & 1.33 & 1.49 \\
\hline & & $\mathrm{Tb}$ & 0.065 & 0.18 & 0.31 \\
\hline Mg\# & 88.3 & Dy & 0.401 & 0.83 & 2.27 \\
\hline \multirow[t]{6}{*}{$\mathrm{Cr} \#$} & 8.5 & Ho & 0.086 & 0.13 & 0.50 \\
\hline & & $\mathrm{Er}$ & 0.239 & 0.31 & 1.46 \\
\hline & & $\mathrm{Tm}$ & 0.034 & 0.04 & 0.22 \\
\hline & & $\mathrm{Yb}$ & 0.220 & 0.21 & 1.35 \\
\hline & & $\mathrm{Lu}$ & 0.034 & 0.03 & 0.21 \\
\hline & & Hf & 0.235 & 0.56 & 0.68 \\
\hline$*$ & Total $\mathrm{Fe}$ as $\mathrm{FeO}$ & $\mathrm{Pb}$ & n.a. $* * *$ & 8.96 & 0.22 \\
\hline$* * \quad \mathrm{I}$ & Loss on Ignition & $\mathrm{Th}$ & 0.083 & 0.11 & 0.05 \\
\hline$* * * \mathrm{r}$ & not analyzed & $\mathrm{U}$ & 0.065 & 0.09 & 0.06 \\
\hline
\end{tabular}

a marked positive $\mathrm{Pb}$ anomaly and slight negative $\mathrm{Ti}$ anomaly, but unlike clinopyroxene, it has slight positive $\mathrm{Zr}$ and $\mathrm{Hf}$ anomalies, and $\mathrm{Nb}$ is elevated relative to $\mathrm{La}$. Interestingly, the normalized contents of $\mathrm{Rb}, \mathrm{Th}$, and $\mathrm{U}$ are comparable in garnet and clinopyroxene.

\subsection{Sr-Nd geochemistry}

\subsubsection{Sm-Nd geochronology}

The Sklené peridotite yields a well-defined $\mathrm{Sm}-\mathrm{Nd}$ isochron age of $338 \pm 13 \mathrm{Ma}$ for clinopyroxene, garnet, and whole rock, with an initial ${ }^{143} \mathrm{Nd} /{ }^{144} \mathrm{Nd}$ ratio of 0.512443 and corresponding $\varepsilon_{\mathrm{Nd}}$ value of -3.8 (Fig. 13, Table 6). This age is the same within error of the mean $\mathrm{Sm}-\mathrm{Nd}$ age, $336 \pm 7 \mathrm{Ma}$, for nine samples of peridotite-hosted pyroxenite and eclogite elsewhere in the Gföhl Assemblage (Medaris et al. 2006a). Such ages are interpreted to represent the time of isotopic closure for these high temperature minerals. These closure ages may be related to the rapid exhumation of the Gföhl Unit, which cooled at a rate of 100 to $150{ }^{\circ} \mathrm{C} / \mathrm{m}$.y., as determined by diffusion modelling of compositionally zoned minerals in the Spačice eclogite (Medaris et al. 2006b) and ${ }^{40} \mathrm{Ar} /{ }^{39} \mathrm{Ar}$ cooling ages of 329-341 Ma for hornblende and 326-329 Ma for muscovite in units overridden by the Gföhl Unit (Dallmeyer et al. 1992).

\subsubsection{Sr and $\mathrm{Nd}$ isotopes}

The Sklené clinopyroxene has an initial $\varepsilon_{\mathrm{Nd}}$ value of +4.5 and an initial ${ }^{87} \mathrm{Sr} /{ }^{86} \mathrm{Sr}$ ratio of 0.7035 (both calculated at $335 \mathrm{Ma}$ ) (Table 6). These values are comparable to those for some samples of Type III peridotite, and they

Tab. $6 \mathrm{Rb}-\mathrm{Sr}$ and $\mathrm{Sm}-\mathrm{Nd}$ isotopic data for the Sklené garnet lherzolite

\begin{tabular}{|c|c|c|c|c|c|c|c|c|c|c|c|c|}
\hline Sample & $\begin{array}{c}\mathrm{Rb} \\
(\mathrm{ppm})\end{array}$ & $\begin{array}{c}\mathrm{Sr} \\
\text { (ppm) }\end{array}$ & ${ }^{87} \mathrm{Rb} /{ }^{86} \mathrm{Sr}$ & ${ }^{87} \mathrm{Sr} /{ }^{86} \mathrm{Sr}$ & ${ }^{87} \mathrm{Sr} /{ }^{86} \mathrm{Sr}(\mathrm{i})$ & $\begin{array}{c}\mathrm{Sm} \\
(\mathrm{ppm})\end{array}$ & $\begin{array}{c}\mathrm{Nd} \\
(\mathrm{ppm})\end{array}$ & ${ }^{147} \mathrm{Sm} /{ }^{144} \mathrm{Nd}$ & ${ }^{143} \mathrm{Nd} /{ }^{144} \mathrm{Nd}$ & $\varepsilon_{\mathrm{Nd}}(\mathrm{i})$ & Age (Ma) & $\mathrm{T}_{\mathrm{DM}}(\mathrm{Ga})$ \\
\hline clinopyroxene & 0.01 & 232 & 0.001 & 0.7035 & 0.7035 & 1.313 & 4.522 & 0.1755 & $0.512825 \pm 10$ & +4.5 & & 0.70 \\
\hline garnet & n.a. & n.a. & n.a. & n.a. & n.a. & 0.629 & 0.588 & 0.6464 & $0.513874 \pm 23$ & +5.2 & $338 \pm 13$ & 0.65 \\
\hline bulk rock & n.a. & n.a. & n.a. & n.a. & n.a. & 0.265 & 0.722 & 0.2221 & $0.512933 \pm 8$ & +4.7 & $338 \pm 13$ & 0.69 \\
\hline
\end{tabular}

Tab. 7 HSE and Re-Os isotopic data for the Sklené garnet lherzolite

\begin{tabular}{lccccccccccc}
\hline Sample & $\mathrm{Re}(\mathrm{ppb})$ & $\mathrm{Os}(\mathrm{ppb})$ & $\mathrm{Ir}(\mathrm{ppb})$ & $\mathrm{Ru}(\mathrm{ppb})$ & $\mathrm{Pt}(\mathrm{ppb})$ & $\mathrm{Pd}(\mathrm{ppb})$ & ${ }^{187} \mathrm{Re} /{ }^{188} \mathrm{Os}$ & ${ }^{187} \mathrm{Os} /{ }^{188} \mathrm{Os}$ & $\gamma_{\mathrm{Os}}$ & $\mathrm{T}_{\mathrm{MA}}(\mathrm{Ma})$ & $\mathrm{T}_{\mathrm{RD}}(\mathrm{Ga})$ \\
\hline CS-SK-1 WR & 0.152 & 3.68 & 3.34 & 6.76 & 5.72 & 1.78 & 0.1997 & 0.12425 & -1.3 & 811 & 0.9 \\
\hline
\end{tabular}

$\gamma_{\mathrm{OS}}$ values calculated back to $335 \mathrm{Ma} . \mathrm{T}_{\mathrm{RD}}$ represents Re depletion age from PUM reservoir (see Shirey and Walker 1998 for details on calculations and Meisel et al. 1996 for PUM values) 

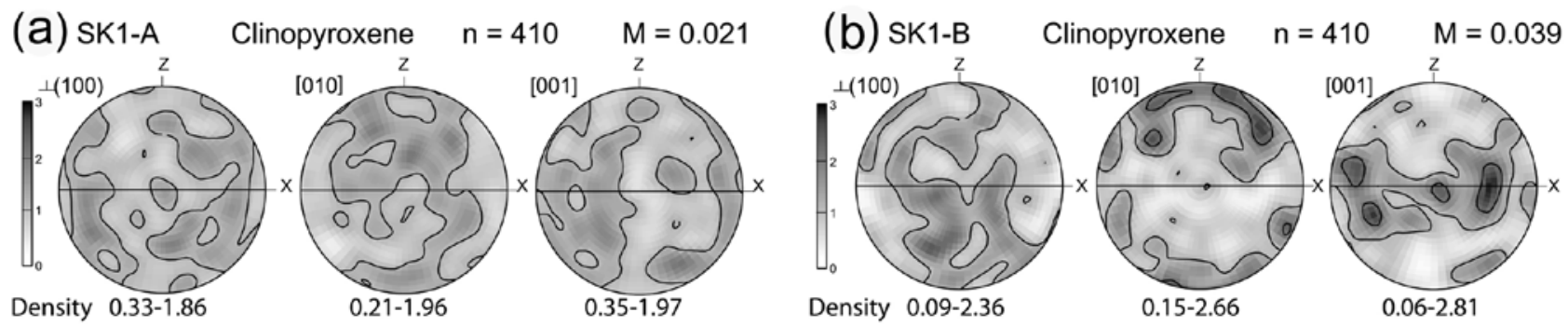

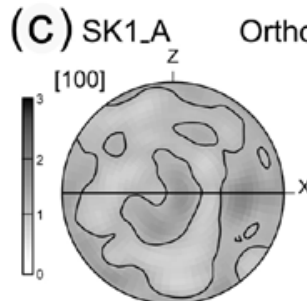

Density $0.56-1.76$

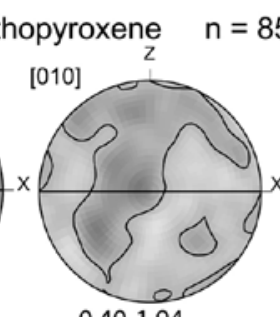

0.40-1.94
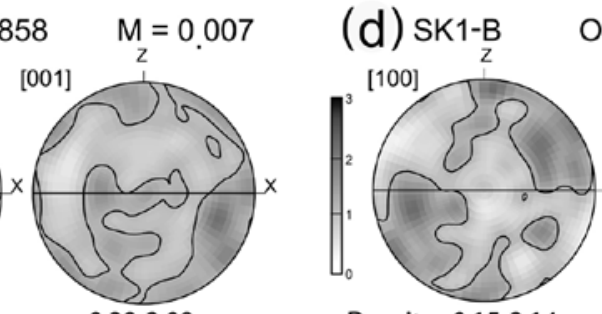

Density $0.15-2.14$

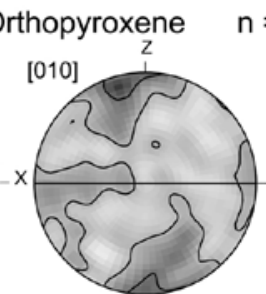

$0.26-2.71$

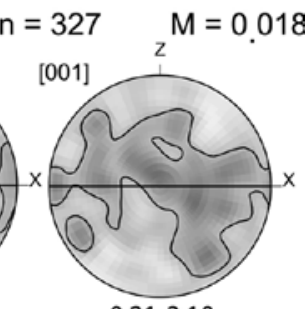

$0.21-2.10$

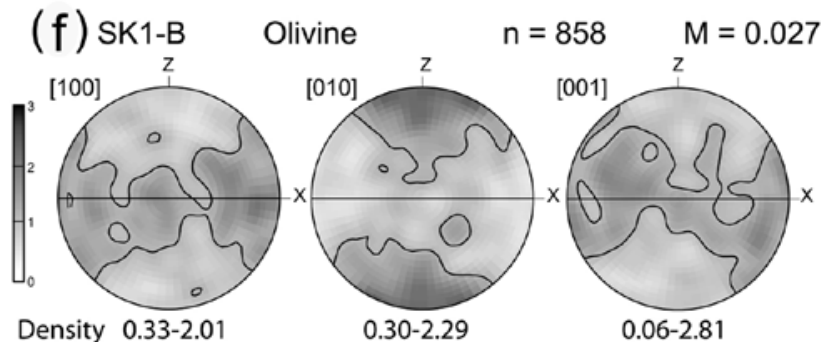

(e) SK1-A Olivine $n=1459 \quad M=0.010$

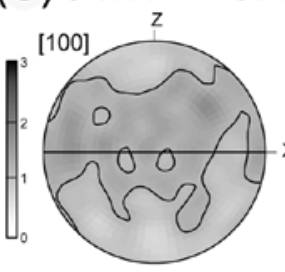

Density $0.51-1.63$

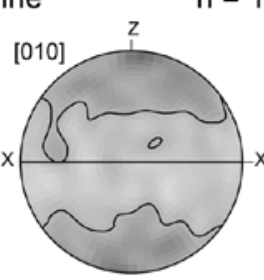

0.52-2.09

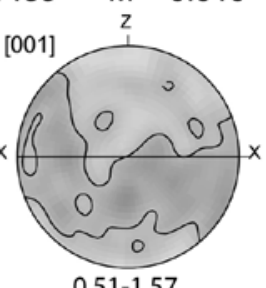

Density $0.33-2.0$

$0.06-2.81$

Fig. 8 Pole figures illustrating LPO of clinopyroxene (a-b), orthopyroxene (c-d), and olivine (e-f), based on one point per grain of map data. Data illustrated in a, $\mathbf{c}$, e were measured in an $\mathrm{X}-\mathrm{Z}$ section; those in $\mathbf{b}, \mathbf{d}, \mathbf{f}$ were measured in an $\mathrm{X}-\mathrm{Y}$ section. Plots are equal area, lower hemisphere projections, oriented with respect to the fabric reference frame, where $\mathrm{X}$ is the lineation and $\mathrm{Z}$ is the pole to foliation. Contouring is multiples of uniform density (m.u.d.), with a contour interval of 1.0. The $M$ values are misorientation indices of Skemer et al. (2005), and indicate relative fabric strengths (higher M-index indicates stronger fabric).

plot within the array defined by clinopyroxenes from peridotite-hosted pyroxenites and eclogites in the Gföhl Assemblage (Fig. 14; Medaris et al. 2006a). Note that samples of Type II-Mg and -Fe peridotite plot outside the pyroxenite-eclogite array, as do two eclogites from the Úhrov peridotite (Fig. 14).

\subsection{Highly siderophile element geochemistry}

Highly siderophile elements (HSE) in the Sklené peridotite, when normalized to the primitive upper mantle (PUM) of Becker et al. (2006), exhibit an unfractionated pattern for the Iridium group PGE (I-PGE: Os, Ir, Ru) and $\mathrm{Pt}$, but a significant depletion in $\mathrm{Pd}$ and Re (Fig. 15, Table 7). This pattern reflects the presence of pentlandite and late-stage heazlewoodite in the Sklené peridotite and their influence on HSE contents. Pentlandite commonly exhibits an unfractionated I-PGE pattern, but significant depletions in Pt and Pd (Luguet et al. 2001). In general, the Sklené HSE pattern is similar to that in Type II-Mg peridotites from Horní Bory, except for a lower Pd content. In contrast, the HSE pattern in Type II Fe peridot- ites from Horní Bory is quite different, showing marked depletion in the I-PGE and a highly fractionated pattern for Pt, Pd, and Re (Fig. 15), similar to that of basalts and eclogites.

The ${ }^{187} \mathrm{Os} /{ }^{188} \mathrm{Os}$ isotopic ratio of the Sklené lherzolite is $0.1242(\gamma \mathrm{Os}=-3.1)$. This value is similar to those for many samples of European subcontinental lithospheric mantle (Meisel et al. 2001; Pearson et al. 2004; Reisberg et al. 2005), but lower compared to PUM (0.1290; Meisel et al. 1996) and estimates for convecting mantle (0.1281; Walker et al. 2002).

\section{Evolution of the Sklené peridotite}

\subsection{Pressure-temperature history}

The texture of the Sklené peridotite reveals three stages of mineralogical development, including an early garnetiferous stage (1), an intermediate stage (2) of matrix recrystallization and deformation accompanied by growth of amphibole in kelyphite and matrix, and a final stage (3) of spinel-orthopyroxene kelyphite development. 

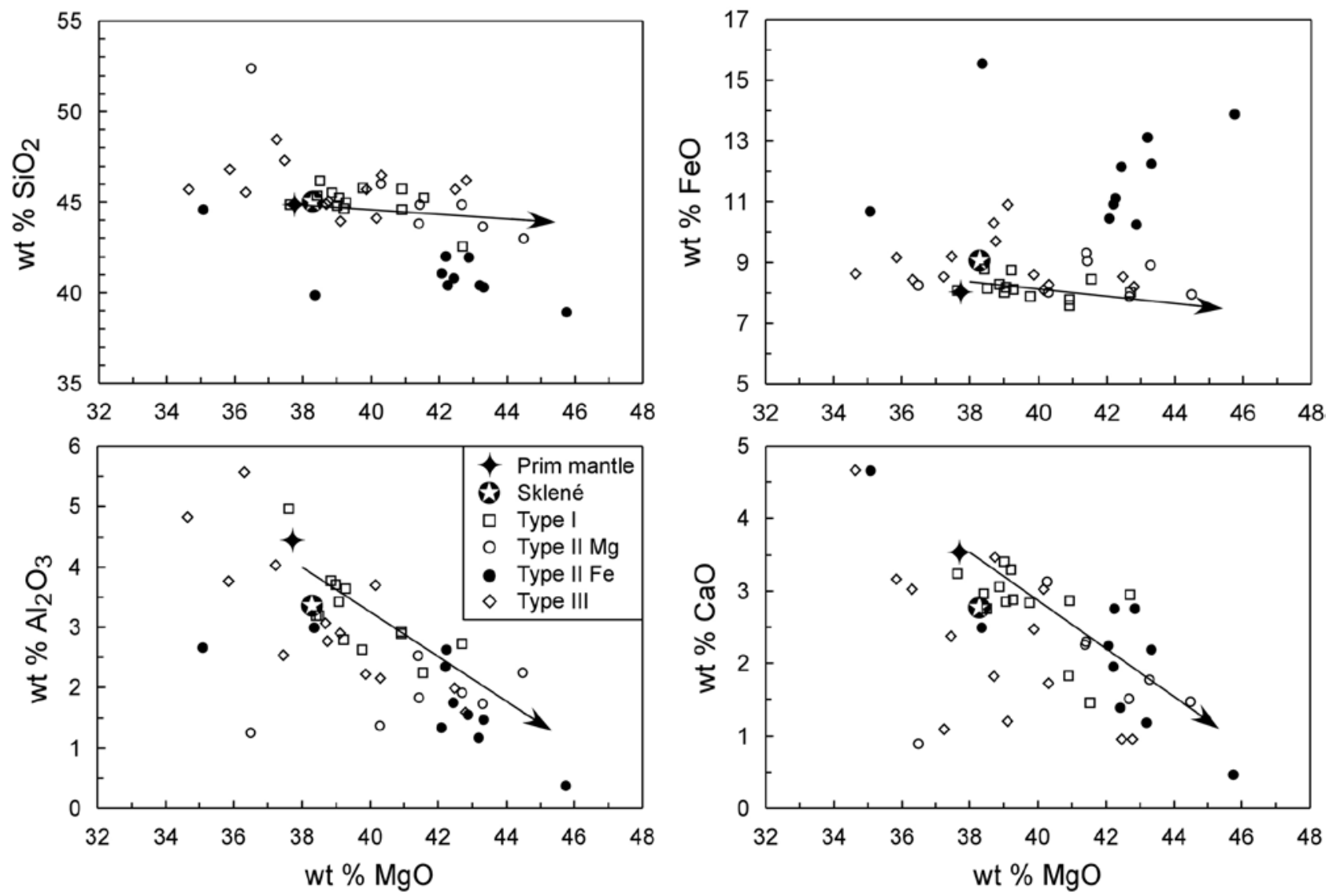

Fig. 9 Variation of whole-rock major oxides, relative to wt. \% MgO, for the Sklené peridotite and other types of Czech peridotites in the Gföhl Assemblage. The composition of primitive mantle (McDonough and Sun 1995) and the variation trend for the Ronda peridotite (Frey et al. 1985) are shown for comparison.

The conventional method for estimating pressure-temperature (PT) conditions for garnet peridotite is to apply the olivine-garnet $\mathrm{Fe}-\mathrm{Mg}$ exchange geothermometer and the Al-in-orthopyroxene barometer to the core compositions of garnet, olivine, and orthopyroxene. The rationale for this method is that $\mathrm{Fe}-\mathrm{Mg}$ diffusion is relatively slow in garnet, $\mathrm{Al}$ diffusion is slow in orthopyroxene, and olivine, because it is the predominant phase in peridotite, will undergo the least compositional change during recrystallization and/or cooling (Brenker and Brey 1997). Note, however, that combination of an exchange reaction and a net transfer reaction will yield meaningful results only if the garnet and orthopyroxene compositions equilibrated at the same time and both were preserved from the PT conditions of interest.

The PT conditions for Stage 1 of the Sklené peridotite were estimated by applying the O'Neill and Wood (1979) calibration of the olivine-garnet $\mathrm{Fe}-\mathrm{Mg}$ exchange geothermometer (corrected by O'Neill 1980) and two calibrations of the Al-in-orthopyroxene geobarometer (Nickel and Green 1985; Brey and Köhler 1990) to the core compositions of garnet, coarser grains of matrix olivine, and coarser grains of matrix orthopyroxene. Re- sults from the two different geobarometer calibrations are similar, $1229^{\circ} \mathrm{C}, 49.1 \mathrm{kbar}$ (Brey and Köhler 1990) and $1242{ }^{\circ} \mathrm{C}, 52.2 \mathrm{kbar}$ (Nickel and Green 1985), and such results are comparable to those for some Czech Type III garnet peridotites (Fig. 16).

The Stage 1 PT estimate for the Sklené peridotite, which lies in a subsolidus regime, is just within the stability field for majoritic garnet (Fig. 16), raising the possibility that the scarce clusters of tiny, acicular grains of orthopyroxene and pargasite in some garnet grains (Fig. 2d) may have originated by exsolution from a majoritic garnet. Similar features have been described in several ultrahigh pressure garnet peridotites elsewhere, e.g. pyroxene lamellae in Norwegian garnet peridotites have been ascribed to pyroxene exsolution from supersilicic garnet (Van Roermund et al. 2001), and pargasite lamellae in Tibetan garnet peridotites are proposed to have originated by amphibole exsolution from supersilicic, $\mathrm{OH}$-bearing garnet (Song et al. 2005). Contents of $\mathrm{H}_{2} \mathrm{O}$ ranging from $<1$ to $290 \mathrm{ppm}$ have been reported in garnet from garnet peridotite xenoliths in kimberlite (Beran and Libowitzky 2006), and if the Sklené garnet contained 200 ppm $\mathrm{H}_{2} \mathrm{O}$, it could account for 0.9 wt. \% exsolved 

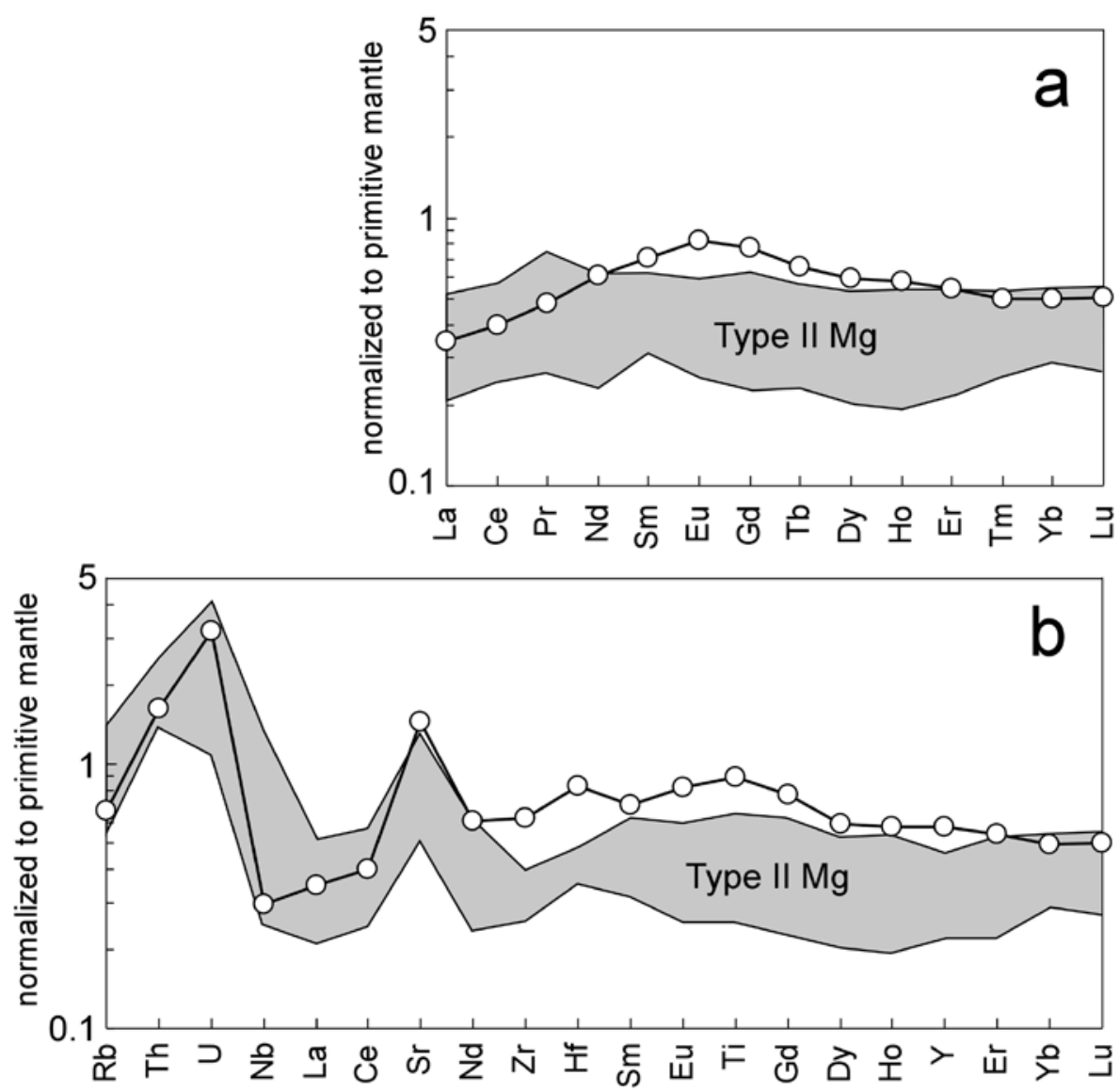

Fig. 10 Whole-rock REE (a) and extended trace element (b) compositions of the Sklené peridotite, normalized to primitive mantle (McDonough and Sun 1995). The compositional fields for Czech Type II Mg peridotites are shown for comparison.

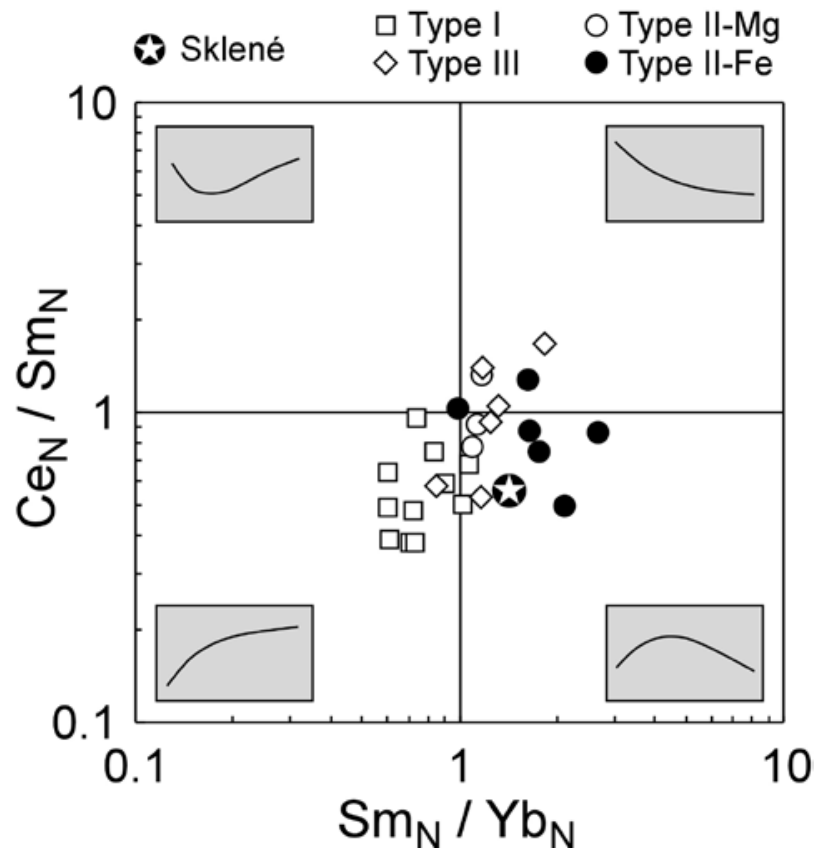

Fig. 11 Ratios of $\mathrm{Ce}_{\mathrm{N}} / \mathrm{Sm}_{\mathrm{N}} v s . \mathrm{Sm}_{\mathrm{N}} / \mathrm{Yb}_{\mathrm{N}}$ for the Sklené peridotite compared to those for other types of Czech peridotites, all normalized to primitive mantle (McDonough and Sun 1995). pargasite. Although no attempt has been made to reconstruct the bulk composition of "exsolved" domains in Sklené garnet, such a calculation would necessarily yield a supersilicic garnet composition, because the $\mathrm{Si} / \mathrm{Al}$ ratios of the acicular grains of orthopyroxene and pargasite (Tables 3 and 4) are higher than those in garnet.

Note, however, that the clusters of pyroxene and pargasite in the Sklené garnet are uncommon, occur near the margins of garnet grains, and consist of minerals that are compositionally similar to those in adjacent kelyphite. Alternatively therefore, it is possible that the clusters of orthopyroxene and pargasite in garnet are related to the introduction of $\mathrm{H}_{2} \mathrm{O}$ into peridotite from the surrounding granulite, development of kelyphite around garnet, and incipient, topotaxial growth of kelyphite minerals in garnet, rather than exsolution from a supersilicic, $\mathrm{OH}$-bearing garnet. Regardless of the source of $\mathrm{H}_{2} \mathrm{O}$ for the growth of pargasite within garnet, such growth must have occurred in the stability field for amphibole at less than $\sim 29$ kbar (Fig. 16), rather than in the majorite field.

Stage 2 in the Sklené sample is represented by the recrystallized matrix, which consists of olivine, orthopyroxene, clinopyroxene, and subordinate pargasite, grains of which are scattered through the matrix and, locally, strung out from kelyphitic rims into the foliation plane of the matrix (Figs 2c and 4c). The presence of pargasite constrains the pressure of Stage 2 to be less than $\sim 29$ kbar (Fig. 16), based on the stability field of pargasite in hydrous peridotite (Schmidt and Poli 1998; Fumagalli and Poli 2005). The temperature for Stage 2 has been estimated by the application of three two-pyroxene geothermometers (Bertrand and Mercier 1985; Brey and Köhler 1990; Taylor 1998) to the mean compositions of fine-grained matrix pyroxenes. All three geothermometers yield similar results, the averages of which range from $900 \pm 39{ }^{\circ} \mathrm{C}$ at $15 \mathrm{kbar}$ to $919 \pm 34{ }^{\circ} \mathrm{C}$ at $25 \mathrm{kbar}$. Based on these constraints and the absence of spinel in the recrystallized matrix, the PT conditions for Stage 2 are judged to be $\sim 915^{\circ} \mathrm{C}$ and $\sim 24$ kbar (Fig. 16). This pres- 

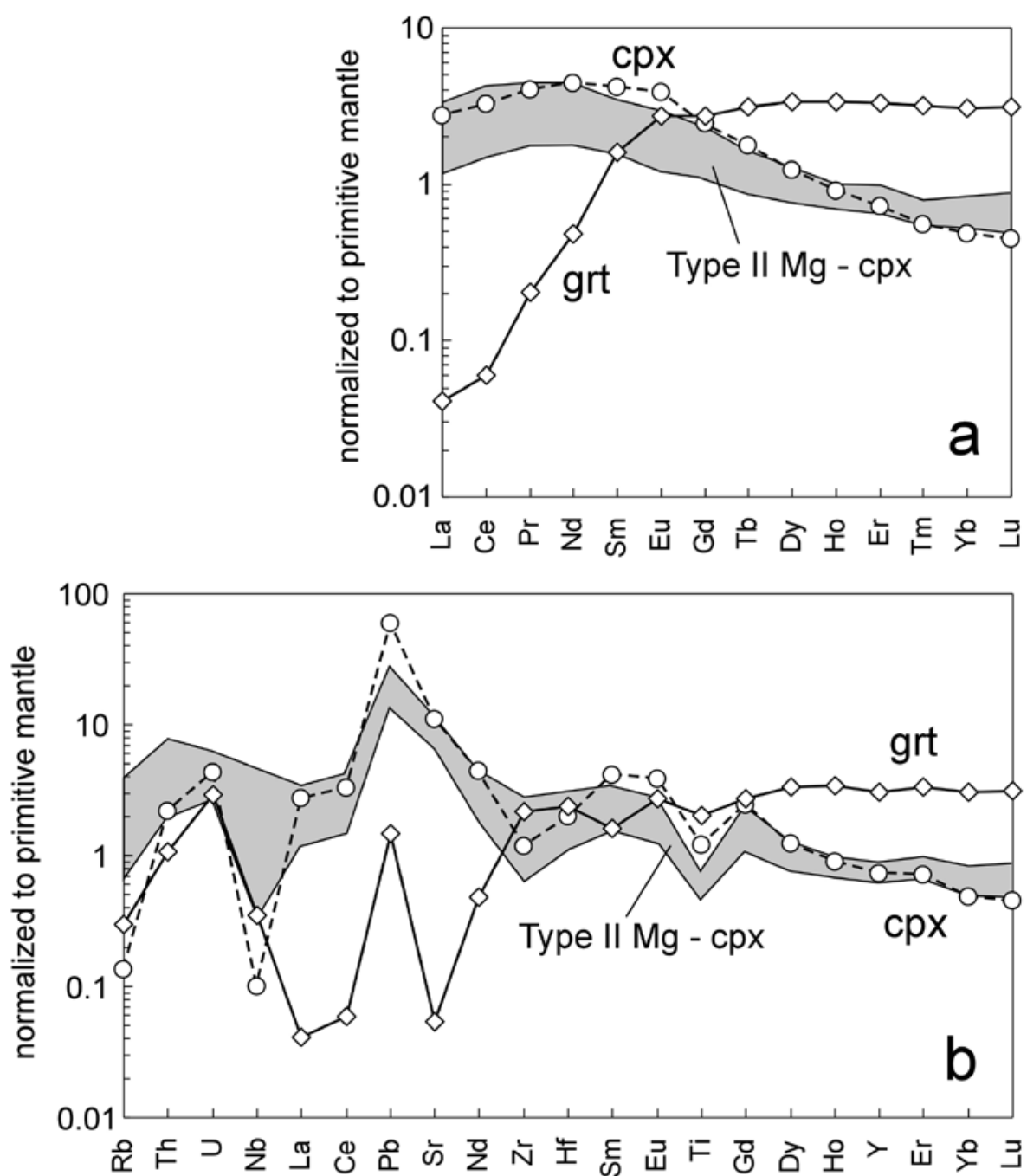

Fig. 12 The REE (a) and extended trace element (b) compositions of clinopyroxene and garnet in the Sklené peridotite, normalized to primitive mantle (McDonough and Sun 1995). The compositional fields for clinopyroxene in Czech Type II Mg peridotites are shown for comparison. sure estimate is slightly above that for the peak metamorphic conditions for Gföhl granulites, which have a broad range, 800 $1000^{\circ} \mathrm{C}, 14-22 \mathrm{kbar}$, depending on specific granulite massif (Schulmann et al. 2005; Vrána et al. 2005; Kotková 2007, and references therein)

Stage 3 is represented by the extremely fine-grained static intergrowth of spinel and orthopyroxene between garnet and pargasite kelyphite, representing the decompression of the Sklené peridotite from the stability field of garnet + olivine + orthopyroxene + clinopyroxene + pargasite to one of spinel + olivine + orthopyroxene + pargasite. The PT conditions for the inner kelyphite of Stage 3 are constrained by the composition of spinel, which has a mean $\mathrm{Cr} \#$ of $11.3 \pm 2.6$ and a corresponding maximum pressure of 17-21 kbar (O'Neill, 1981), and the absence of chlorite. Accordingly, Stage 3 has been placed below this pressure limit and above the chlorite stability field, at a temperature of $\sim 900^{\circ} \mathrm{C}$ (Fig. 16).

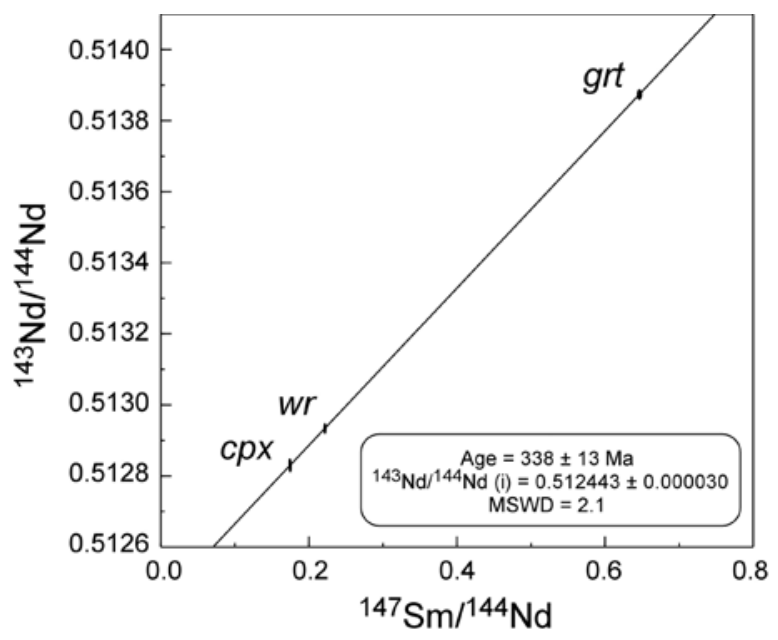

Fig. $13 \mathrm{Sm}-\mathrm{Nd}$ isochron for the Sklené garnet lherzolite.

\subsection{Mantle geochemical processes}

Many samples of mantle peridotite commonly record the effects of two geochemical processes: 1) initial depletion of incompatible elements by partial melting, and 2) subsequent modification of certain elements and isotopic ratios by reaction of peridotite with infiltrating melts or fluids (e.g., basaltic melts, carbonatitic melts, or fluids, either $\mathrm{H}_{2} \mathrm{O}$-rich or $\mathrm{CO}_{2}$-rich).

Although the Sklené peridotite is a relatively fertile lherzolite, which contains $10 \%$ clinopyroxene, its $\mathrm{Al}_{2} \mathrm{O}_{3}$, $\mathrm{CaO}, \mathrm{Na}_{2} \mathrm{O}, \mathrm{TiO}_{2}$, and REE contents, when compared to those of primitive mantle (Table 5; Figs 9 and 10a), indicate that the Sklené peridotite experienced a small amount of partial fusion and depletion in incompatible elements. A quantitative calculation of the degree of depletion, based on the $\mathrm{Yb}$ and $\mathrm{Y}$ contents of clinopyroxene in equilibrium with melt (Norman 1998), is pre- 
Fig. $14 \varepsilon_{\mathrm{Nd}} v s .\left({ }^{87} \mathrm{Sr} /{ }^{86} \mathrm{Sr}\right){ }_{\mathrm{i}}$ for Sklené clinopyroxene compared to clinopyroxene in other types of Czech peridotites and the array defined by clinopyroxene in peridotite-hosted pyroxenites and eclogites (Ackerman et al. 2009, and references therein). Mantle components, DMM, EM1, and EM2, from Harte (1988). All data calculated at $335 \mathrm{Ma}$.
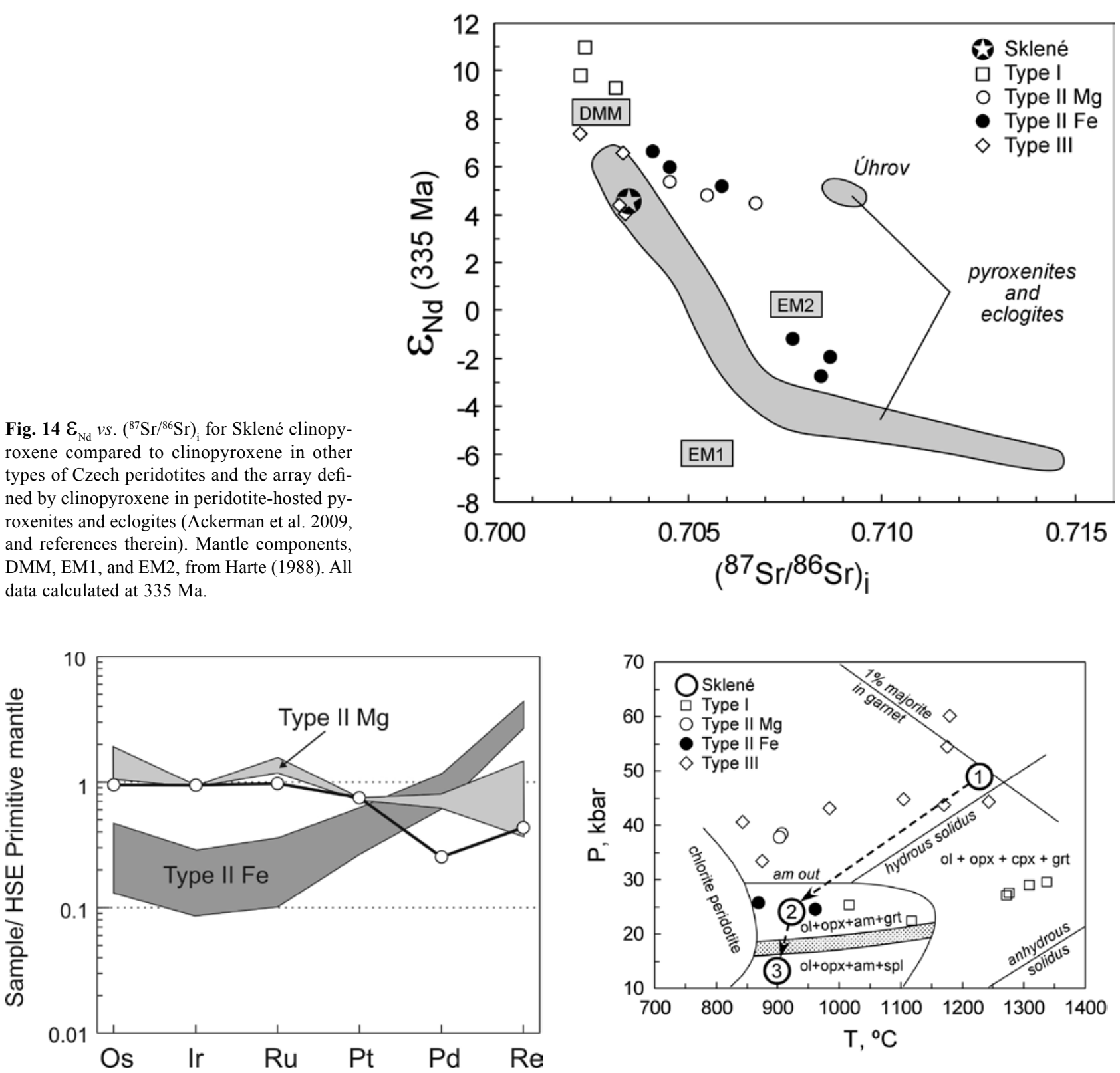

Fig. 15 The HSE pattern of Sklené peridotite, normalized to primitive upper mantle (PUM; Becker et al. 2006). The HSE compositions of Type II Mg and Type II Fe peridotites are shown for comparison (Ackerman, unpublished data).

cluded, however, because of the likely modification of initial clinopyroxene composition by high-temperature, subsolidus re-equilibration with garnet. Qualitatively, the low normalized values, $\sim 0.5$, for the HREE in the Sklené peridotite (Fig. 10a) indicate that partial fusion and melt extraction may have occurred in the spinel stability field, prior to stabilization of garnet at high pressures, otherwise the HREE contents in the peridotite residuum would have remained near a value of 1.0 in the presence of garnet during low to moderate degrees of partial fusion.

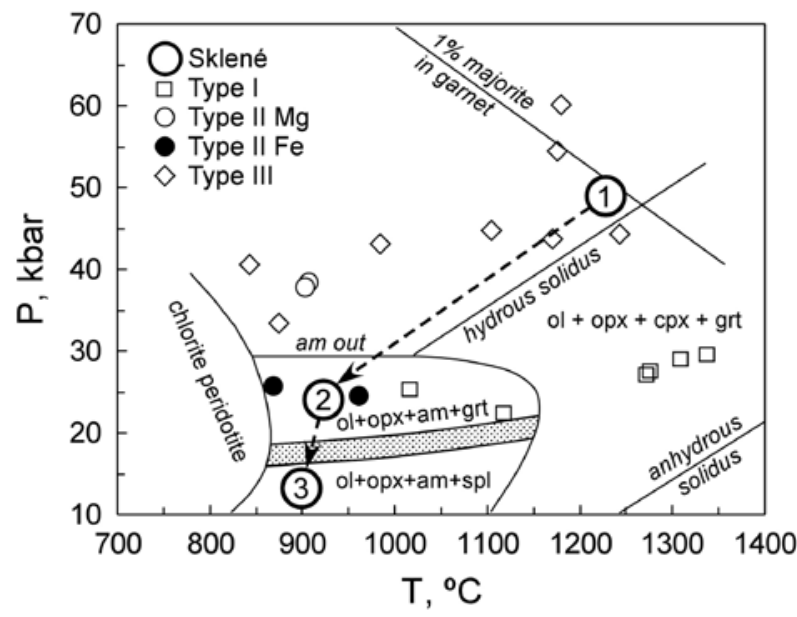

Fig. 16 Pressure-temperature (PT) estimates for the three textural and mineralogical stages of the Sklené peridotite. PT estimates for garnetiferous assemblages in other types of Czech garnet peridotites are shown for comparison. Mineralogical stability fields from Fumagalli and Poli (2005) and Poli and Schmidt (1998); upper pressure limit of spinel calculated from O'Neill (1981); majorite isopleth from Gasparik (2003); anhydrous and hydrous $\left(200 \mathrm{ppm} \mathrm{H}_{2} \mathrm{O}\right)$ solidi for fertile lherzolite from Green and Falloon (2005).

Compared to primitive mantle, the Sklené peridotite has a lower Mg\#, 88.3 vs. 89.3 , and higher contents of (and positive anomalies for) $\mathrm{Th}, \mathrm{U}$, and $\mathrm{Sr}$ (Fig. 10b). Clinopyroxene and garnet also have positive anomalies for $\mathrm{Th}$ and $\mathrm{U}$ and pronounced positive anomalies for $\mathrm{Pb}$ (Fig. 12b), and clinopyroxene has a marked negative $\mathrm{Nb}$ anomaly (Fig. 12b). With respect to the HSE in peridotite, 

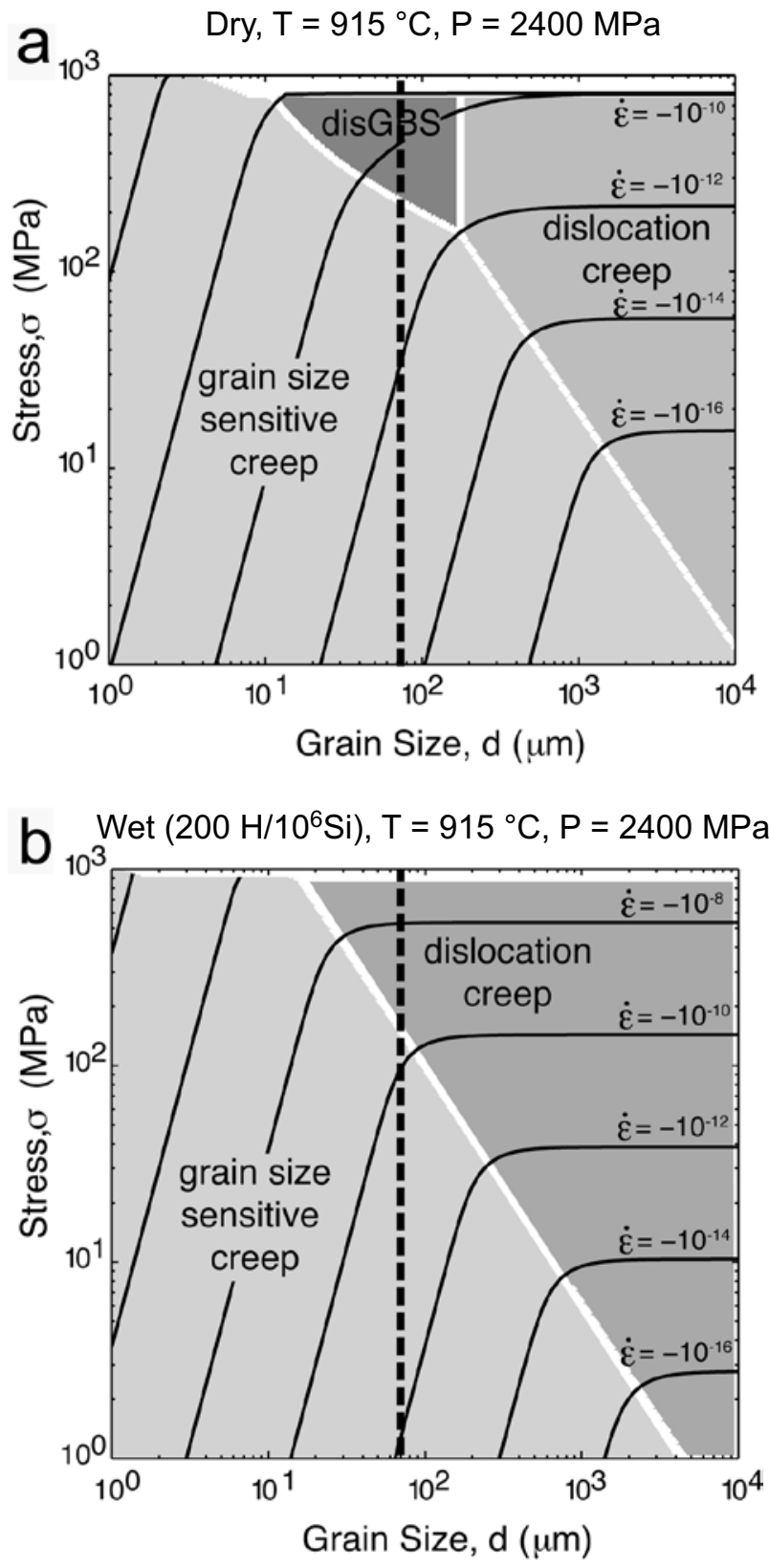

Fig. 17 Deformation mechanism maps for (a) dry olivine and (b) wet olivine $\left(200 \mathrm{H} / 10^{6} \mathrm{Si}\right)$ at $915^{\circ} \mathrm{C}$ and $2400 \mathrm{MPa}$, as experienced during Stage 2 deformation. The maps were constructed using constitutive equations described by Warren and Hirth (2006). The estimated mean matrix grain size, $70 \mu \mathrm{m}$, is indicated by the vertical dashed line. disGBS $=$ dislocation-accommodated grain boundary sliding.

the normalized content of Re is greater than that for Pd (Fig. 15), despite Re being less compatible than Pd (e.g., Pearson et al. 2004). All of these features indicate that the Sklené peridotite experienced some degree of cryptic metasomatism, with addition of $\mathrm{Fe}, \mathrm{Th}, \mathrm{U}, \mathrm{Pb}, \mathrm{Sr}$, and $\mathrm{Re}$, coupled with removal of $\mathrm{Nb}$ from clinopyroxene.

Although it appears that the Sklené peridotite has been enriched in $\mathrm{Sr}$, there is no evidence for this in the ${ }^{87} \mathrm{Sr} /{ }^{86} \mathrm{Sr}$ ratio of its clinopyroxene, which is only slightly higher, 0.7035, than that for depleted MORB mantle (DMM; Fig. 14). We suggest that the metasomatic $\mathrm{Sr}$ was relatively unradiogenic, having been derived from an isotopically primitive or depleted mantle source, thereby having little effect on the ${ }^{87} \mathrm{Sr} /{ }^{86} \mathrm{Sr}$ composition of the Sklené clinopyroxene. The Sklené Os isotopic composition is also relatively unradiogenic $(\gamma \mathrm{Os}=-1.3)$, indicating little or no addition of radiogenic Os.

In summary, the geochemical characteristics of the Sklené peridotite are consistent with some degree of cryptic metasomatism, most likely produced by transient, primitive mantle-derived melts of basaltic composition. In contrast to the neighbouring Horní Bory ultramafic suite (Ackerman et al. 2009), there is no evidence for subduction-related metasomatism and melt-rock reaction in the Sklené peridotite.

Although partitioning of Re between crystals and silicate melt is dependent on oxygen fugacity, Re behaves as a moderately to strongly incompatible element in the range of oxygen fugacities commonly assigned to the mantle, e.g. $\Delta \log f \mathrm{O}_{2}(\mathrm{QFM})=-2$ to +2 (Mallman and O'Neill 2007). Because Os is a compatible element, $\mathrm{Re} / \mathrm{Os}$ ratios in peridotite residua will decrease during partial fusion, which offers a method for estimating the age of melt extraction, provided that neither Re nor Os of different isotopic compositions were subsequently added to the system. The model Re-depletion age $\left(\mathrm{T}_{\mathrm{RD}}\right.$; Table 7; Walker et al. 1989) for the Sklené peridotite is $0.9 \mathrm{Ga}$. However, because of the likely metasomatic addition of $\mathrm{Re}$, this age is probably a minimum estimate for the time of melt extraction. The $\mathrm{T}_{\mathrm{RD}}$ age for Sklené is within the large range $(0.3-2.0 \mathrm{Ga})$ of those for several other European orogenic peridotites (e.g., Ronda, Lherz, and Lanzo; Becker et al. 2006), which show evidence for mantle refertilization, but slightly lower than those $(1.0-1.5 \mathrm{Ga})$ for most Lower Austrian peridotites (Becker et al. 2001).

\subsection{Deformation and recrystallization}

The textural characteristics of the matrix of the Sklené peridotite developed during Stage 2 deformation, coeval with or postdating formation of the pargasitic kelyphite, which has been drawn out into the matrix. The PT conditions for deformation are therefore $\sim 900{ }^{\circ} \mathrm{C}$ and $\sim 24$ $\mathrm{kbar}$, corresponding to a depth of $\sim 80 \mathrm{~km}$, assuming a 30 $\mathrm{km}$ thick crust with $\rho=2750 \mathrm{~kg} / \mathrm{m}^{3}$ underlain by mantle with $\rho=3200 \mathrm{~kg} / \mathrm{m}^{3}$. The presence of recognizable LPOs in olivine, orthopyroxene and clinopyroxene indicate that all these phases deformed in part by dislocationaccommodated creep.

The petrofabrics are relatively weak, reflected in their low M-indices (cf., Skemer et al. 2005). This 
pattern could have several possible causes, including: 1) the peridotites have experienced insufficient strain for strong fabrics to form; 2) initially strong fabrics have been weakened, due either to post-deformational static annealing (e.g., Wightman et al. 2006) or activation of grain size sensitive deformation mechanisms (Skemer and Karato 2008); or 3) the type of kinematics does not produce strong petrofabrics.

The average matrix grain size, $70 \mu \mathrm{m}$, is consistent with the operation of grain size sensitive creep for reasonable geological strain rates $\left(<10^{-10} \mathrm{~s}^{-1}\right.$; Pfiffner and Ramsay 1982) for both dry and wet olivine $\left(200 \mathrm{H} / 10^{6} \mathrm{Si}\right)$, as illustrated in Fig. 17. The relatively polygonal matrix microstructures, including straight grain boundaries and $120^{\circ}$ triple junctions, are consistent with either low total strain or post-deformational annealing, but the straight grain boundaries would also facilitate grain boundary sliding. One possible interpretation of these various microstructural and textural data is a history of changing deformation mechanisms during progressive deformation. In this scenario, initial grain size reduction and formation of a porphyroclast and matrix microstructure occurred by dislocation creep. Once grain size was reduced sufficiently by this process, however, the rock began to deform by grain size sensitive creep (cf. Warren and Hirth 2006; Skemer and Karato 2008; Toy et al. in print).

The observed pyroxene LPOs (Fig. 8) are consistent with glide on the (010) plane during the initial dislocation creep phase, which is not typically reported for pyroxenes (except by Toy et al. in print, and in omphacite in natural eclogites; Bascou et al. 2002). The girdles of [001] in the $\mathrm{X}-\mathrm{Y}$ plane are similar to S-type petrofabrics of Helmstedt et al. (1972), which may form due to glide parallel to this crystallographic axis during a flattening-dominated deformation, producing an oblate strain ellipsoid (Ulrich and Mainprice 2001).

Olivine LPOs (Fig. 8) are consistent with glide on (010) parallel to [100] and [001]. Such LPOs differ from typical olivine patterns diagnostic of (010)[100] and (010) [001] glide during dislocation creep, which would have concentrations of [100] and [001], respectively, parallel to fabric X. Sundberg and Cooper (2008) also reported similar LPOs in fine-grained olivine-orthopyroxene aggregates experimentally deformed by diffusion creep in general shear. However, we think it is most likely that the observed LPOs were developed during an initial stage of dislocation creep, because of the porphyroclast and matrix microstructure and matrix grain elongation. Consequently, we suggest that the observed olivine LPOs were developed in a flattening-dominated deformation regime.

(010)[100] is the slip system most commonly reported to have been activated in olivine under upper mantle conditions in naturally-deformed peridotites (e.g. van der Wal and Vissers 1993; Dijkstra et al. 2001, 2002) and in experimental studies under relatively low differential stresses and low water contents (e.g. Carter and Ave'Lallemant 1970; Jung and Karato 2001). With higher water contents, we might expect olivine LPO diagnostic of glide on the system (010)[001] (Type B fabric of Jung and Karato 2001). During Stage 2 deformation of the Sklené peridotite, water contents must have been high enough to stabilize pargasite, suggesting that conditions were consistent with those necessary to develop a Type B fabric. The other alternative is that the observed fabrics reflect the kinematics of deformation; numerical simulations of Tommasi et al. (1998) illustrated that different LPO geometries are expected for different magnitudes and types of deformation. Thus, the LPOs for Sklené olivine, which are consistent with both Type A and Type B fabrics, could be the result of either: 1) water content causing activation of different slip systems in a simple shear deformation; 2) three-dimensional kinematics; or 3) some combination of the two.

At lower temperatures, glide in olivine is expected to occur on the system $\{0 \mathrm{kl}\}[100]$ (Carter and Ave'Lallemant 1970). The absence of LPOs diagnostic of operation of this slip system, and the presence of static Stage 3 kelyphite rims formed at $\sim 900{ }^{\circ} \mathrm{C}$ and 17-21 kbar, indicate that the Sklené peridotite was not substantially deformed after it was incorporated into the Bory granulite.

Grain shape fabrics are more strongly developed immediately adjacent to garnet porphyroclasts, indicating that matrix strain was focussed in these areas, probably to maintain constant bulk strain rate around the relatively rigid garnets. The kelyphitic pargasite trails define a delta geometry (Figs 2c, 4c), indicating that the rigid garnet porphyroclasts rotated, consistent with non-coaxial deformation during Stage 2 deformation. Although not well developed, shear sense indicators are present as denoted by larger grain size in the strain shadow areas, presence of fine-grained material along the garnet's margins, and local imbrication of garnets. Shear sense indicators are best developed with a consistent sense of shear in the $\mathrm{Y}-\mathrm{Z}$ plane. This type of pattern is expected for pure-shear dominated transpressional deformation (e.g., Fossen and Tikoff 1993). Numerical modelling of olivine LPO development in transpression deformation also shows results that are consistent with the observed patterns (Tommasi et al. 1998). Consequently, we interpret that the Sklené peridotite was deformed during "transpressional" deformation (widening/thinning shear of Tikoff and Fossen 1993) that produced an oblate strain ellipsoid. We also interpret the observed pyroxene LPO patterns as reflecting this transpressional deformation. Given the relatively poor development of shear sense indicators, we cannot unambiguously rule out the possibility of a flattening- 
dominated non-coaxial shear, which would also produce an oblate strain ellipsoid (lengthening-widening shear of Tikoff and Fossen 1993).

We emphasize that the enclave nature of the Sklené outcrop does not allow us to explicitly link these fabrics to spatial orientations with respect to the development of the Variscan orogen. Consequently, the "transpressional" fabric does not necessarily require a transcurrent component of displacement for the mountain belt, although the fabrics are consistent with transpressional deformation inferred for the orogen by Schulmann et al (2005).

\section{Conclusions}

The patent and cryptic features of the Sklené peridotite, as described above, reveal a prolonged evolution from its inception in the mantle to its incorporation in the Bory granulite, as summarized in the following sequence of events:

- early partial fusion, melt extraction, and depletion of incompatible elements at moderate pressures in the spinel stability field,

- stabilization of garnet under high-pressure conditions in a subsolidus regime at $\sim 1230^{\circ} \mathrm{C}$ and $50 \mathrm{kbar}$, slightly within the stability field of majoritic garnet,

- metasomatic addition of $\mathrm{Rb}, \mathrm{Th}, \mathrm{U}, \mathrm{Pb}$, and $\mathrm{Sr}$ by transient, primitive basaltic melts,

- dynamic recrystallization, possibly with a gradual transition to grain size sensitive creep, at $\sim 915^{\circ} \mathrm{C}$ and 24 kbar, accompanied by stabilization of pargasitic amphibole and development of [010] maxima and [100] and [001] girdles in olivine in a flattening-dominated, transpressive deformation regime, prior to incorporation in granulite, but likely reflecting the early stages of convergence between Brunia and Moldanubia,

- local, static recrystallization and growth of spinel within kelyphite at $\sim 900^{\circ} \mathrm{C}$ and $17-21 \mathrm{kbar}$, probably after incorporation in granulite and isofacial with granulite peak metamorphism,

- and finally, development of a talc-amphibole reaction rim between peridotite and granulite, due to the instability of olivine with quartz and plagioclase in the presence of a hydrous fluid phase.

The Sklené peridotite yields a $\mathrm{Sm}-\mathrm{Nd}$ mineral isochron cooling age of $338 \pm 13 \mathrm{Ma}$, which is comparable to that for other Variscan garnet peridotites, pyroxenites, and eclogites in the Gföhl Terrane. With respect to mineral paragenesis, PT conditions, major-element composition, and $\mathrm{Nd}$ and $\mathrm{Sr}$ isotopic compositions, the Sklené peridotite is most similar to Type III subcontinental lithosphere. However, the pattern of trace-element metasomatism resembles that in Type II-Mg peridotite in the nearby Horní Bory quarry. Thus, we suggest that the
Sklené peridotite represents a fragment of Type III subcontinental lithosphere, which experienced only incipient effects of Type II metasomatism, in contrast to the more pervasive metasomatism recorded by Type II $\mathrm{Mg}$ and $\mathrm{Fe}$ peridotites in the Horní Bory quarry.

Garnet peridotites in the Gföhl Terrane include a diversity of mantle lithologies and histories, and each peridotite occurrence must be investigated in detail to reveal the full panorama of mantle evolution in the Variscan orogenic belt.

Acknowledgements We are indebted to John Fournelle for his direction and assistance with EMP and SEM operation. Istvan Kovacs and Stanislav Ulrich provided constructive reviews that led to improvement of the manuscript. This research was supported by the Grant Agency of the Academy of Sciences, Project No. KJB300130902 (to Ackerman), the Scientific Programme CEZ: AV0Z30130516 of the Institute of Geology, Acad. Sci. CR, MSM 0021620855 of Charles University, Faculty of Science, and National Science Foundation Grant EAR-0409522 (to Toy and Tikoff).

Electronic supplementary material. The online version of this article (doi: 10.3190/jgeosci.052) contains supplementary electronic material.

\section{References}

Ackerman L, Jelínek E, Medaris G Jr, Ježek J, Siebel W, STRNAD L (2009) Geochemistry of Fe-rich peridotites and associated pyroxenites from Horní Bory, Bohemian Massif: Insights into subduction-related melt-rock reactions. Chem Geol 259: 152-167

Altherr R, Kalt A (1996) Metamorphic evolution of ultrahigh-pressure garnet peridotites from the Variscan Vosges Mts. (France). Chem Geol 134: 27-47

Armstrong, JT (1988) Quantitative analysis of silicate and oxide materials: comparison of Monte Carlo, ZAF, and $\varphi(\rho z)$ procedures. In: NewBuRy DE (ed) Microbeam Analyses, Proceedings of the $23^{\text {rd }}$ Annual Conference of the Microbeam Analysis Society. San Francisco Press, San Francisco, pp 239-246

Bascou J, Tommasi A, Mainprice D (2002) Plastic deformation and development of clinopyroxene lattice-preferred orientation in eclogites. J Struct Geol 24: 1357-1368

Beard BL, Medaris LG, Johnson CM, Jelínek E, Tonika J, Riciputi LR (1995) Geochronology and geochemistry of eclogites from the Mariánské Lázně Complex, Czech Republic: implication for Variscan orogenesis. Geol Rundsch 84: 552-567

Becker H, Shirey SB, Carlson RW (2001) Effects of melt percolation on the Re-Os systematics of peridotites from 
a Paleozoic convergent plate margin. Earth Planet Sci Lett 188: 107-121

Becker H, Horan MF, Walker RJ, Gao S, Lorand JP, RudNICK RL (2006) Highly siderophile element compositions of the Earth's primitive mantle. Geochim Cosmochim Acta 70: 4528-4550

Beran A, Libowitzky E (2006) Water in natural mantle minerals II: olivine, garnet and accessory minerals. In: Keppler H, Smyth JR (eds) Water in Nominally Anhydrous Minerals, Rev Mineral Geochem 62: 169-191

Bertrand P, Mercier J-CC (1985) The mutual solubility of coexisting ortho- and clinopyroxene: toward an absolute geothermometer for the natural system? Earth Planet Sci Lett 76: 109-122

Bestmann M, Prior DJ (2003) Intragranular dynamic recrystallization in naturally deformed calcite marble: diffusion accommodated grain boundary sliding as a result of subgrain rotation recrystallisation. J Struct Geol 25: 1597-1613

Birck JL, Barman MR, CAmpas F (1997) Re-Os isotopic measurements at the fentomole level in natural samples. J Geostand Geoanal 21: 19-27

BRenKer FE, BRey GP (1997) Reconstruction of the exhumation path of the Alpe Arami garnet-peridotite body from depths exceeding $160 \mathrm{~km}$. J Metamorph Geol 15:581-592

BREY GP, KÖHLER T (1990) Geothermobarometry in fourphase lherzolites II. New thermobarometers, and practical assessment of existing thermobarometers. J Petrol 31: 1352-1378

Carter NL, Ave'Lallemant HG (1970). High temperature flow of dunite and peridotite. Geol Soc Am Bull 81: 2181-2202

CARSwELl DA (1991) Variscan high P-T metamorphism and uplift history in the Moldanubian Zone of the Bohemian Massif in Lower Austria. Eur Jour Mineral 3: 323-342

Сна́в J (1973) An ancient oceanic crust and upper mantle on the recent land surface. Věst Ústř Úst Geol 48: 303-310 (in Czech)

Cohen AS, Waters FG (1996) Separation of osmium from geologic materials by solvent extraction for analysis by TIMS. Anal Chim Acta 332: 269-275

Dallmeyer RD, Neubauer F, Höck V (1992) Chronology of late Paleozoic tectonothermal activity in the southeastern Bohemian Massif, Austria (Moldanubian and Moravo-Silesian zones): ${ }^{40} \mathrm{Ar} /{ }^{39} \mathrm{Ar}$ mineral age controls. Tectonophysics 210: 135-153

DePaolo DJ, Wasserburg GJ (1976) Nd isotope variations and petrogenetic models. Geophys Res Lett 4: 465-468

DiJKstRa AH, DruRY M, VisSers RLM (2001) Structural petrology of plagioclase peridotites in the West Othris Mountains (Greece): Melt impregnation in mantle lithosphere. J Petrol 42: 5-24
DijKstra AH, DruRY M, FriJhoff RM (2002) Microstructures and lattice fabrics in the Hilti mantle section (Oman Ophiolite): evidence for shear localization and melt weakening in the crust-mantle transition zone? J Geophys Res 107 (B11): 2270

Fiala J (1966) The distribution of elements in mineral phase of some garnet peridotites from the Bohemian Massif. Krystalinikum 4: 31-53

Fossen H, Tikoff B (1993) The deformation matrix for simultaneous simple shearing, pure shearing, and volume change, and its application to transpression/transtension tectonics. J Struct Geol 15: 413-422

Frey FA, Suen CJ, Stockman HW (1985) The Ronda high temperature peridotite: geochemistry and petrogenesis. Geochim Cosmochim Acta 49: 2469-2491

Fumagalli P, Poli S (2005) Experimentally determined phase relations in hydrous peridotites to $6.5 \mathrm{GPa}$ and their consequences on the dynamics of subduction. J Petrol 46: 555-578

Gardien V, Tegyet M, Lardeaux JM, Misseri M, Dufour E (1990) Crust-mantle relationships in the French Variscan chain: the example of the Southern Monts du Lyonnais Unit (eastern French Massif Central). J Metamorph Geol 8: 477-492

Gasparik T (2003) Phase Diagrams for Geoscientists An Atlas of the Earth's Interior. Springer, Berlin, pp $1-350$

Green DH, Falloon TJ (2005) Primary magmas at midocean ridges, "hotspots", and other intraplate settings: constraints on mantle potential temperature. In: FoULGER GR, Natland JH, Presnall DC, Anderson DL (eds) Plates, Plumes, and Paradigms. Geological Society of America Special Papers 388: 217-247

HARTE SR (1988) Heterogeneous mantle domains: signatures, genesis and mixing chronologies. Earth Planet Sci Lett 90: 273-296

Hartley AJ, Otava J (2001) Sediment provenance and dispersal in a deep marine foreland basin: the Lower Carboniferous Culm Basin, Czech Republic. J Geol Soc, London 158: 137-150

Helmstaedt H, Anderson OL, Gavasci AT (1972) Petrofabric studies of eclogite, spinel-websterite, and spinellherzolite xenoliths from kimberlite-bearing breccia pipes in southeastern Utah and northeastern Arizona. J Geophys Res 77: 4350-4365

Höck V, Petrakakis K, Richter W (1997) Metamorphic evolution of the southeastern Bohemian Massif. Mineral Petrol 60: 267-287

JACOBSEN SB, WaSSERBURG GJ (1980) Sm-Nd isotopic evolution of chondrites. Earth Planet Sci Lett 50: 139-155

Jelínek E, PaČesová M, Mísař Z, Martinec P, Weiss Z (1984) Geochemistry of a dismembered metaophiolite complex, Letovice, Czechoslovakia. Trans Roy Soc Edinb, Earth Sci 75: 37-48 
JELÍNEK E, ŠTĚDRÁ V, CHÁB J (1997) The Mariánské Lázně Complex. In: VRÁNA S, ŠTĚDRÁ V (eds) Geological Model of Western Bohemia Related to the KTB Borehole in Germany. Czech Geological Survey, Prague pp 61-70

JunG H, KARATO S-I (2001) Water-induced fabric transitions in olivine. Science 293: 1460-1462

Kalt A, Altherr R (1996) Metamorphic evolution of garnet-spinel peridotites from the Variscan Schwarzwald (F.R.G.). Geol Rundsch 85: 211-224

Kalt A, Altherr R, Hanel M (1995) Contrasting P-T conditions recorded in ultramafic high-pressure rocks from the Variscan Schwarzwald (F.R.G.). Contrib Mineral Petrol 121: 45-60

Kastl E, Tonika J (1984) The Mariánské Lázně metaophiolitic complex (west Bohemia). Krystalinikum 17: 59-76

KotKovÁ J (2007) High-pressure granulites of the Bohemian Massif: recent advances and open questions. J Geosci 52: $45-71$

Kotková J, Melichar R., Pokorná J (2003): Story of Bory granulites - early thoughts. Proceedings of the $8^{\text {th }}$ Meeting of the Czech Tectonic Studies Group, Hrubá Skála, Czech Republic. Geolines 16: 57

LASNIER B (1971) Les peridotites et pyroxenolites a grenat du Bois des Feuilles (Monts du Lyonnais) (France). Contrib Mineral Petrol 34: 29-42

Liew TC, Hofmann AW (1988) Precambrian crustal components, plutonic associations, plate environment of the Hercynian Fold Belt of central Europe: indications from a Nd and $\mathrm{Sr}$ isotopic study. Contrib Mineral Petrol 98: 129-138

LuDwiG KR (2003) Isoplot 3.00 - a Geochronological Toolkit for Microsoft Excel. Berkeley Geochronology Center, Spec Publ No. 4, pp 1-70

Luguet A, Alard O, Lorand JP, Pearson NJ, Ryan C, O'ReILly SY (2001) Laser-ablation microprobe (LAM)ICPMS unravels the highly siderophile element geochemistry of the oceanic mantle. Earth Planet Sci Lett 189: 285-294

MACHART J (1984) Ultramafic rocks in the Bohemian part of the Moldanubicum and central Bohemian Islet Zone (Bohemian Massif). Krystalinikum 17: 13-32

Mallmann G, O’Neill HStC (2007) The effect of oxygen fugacity on the partitioning of Re between crystals and silicate melt during mantle melting. Geochim Cosmochim Acta 71: 2837-2857

McDonough WF, Sun S (1995) The composition of the Earth. Chem Geol 120: 223-253

Medaris LG JR, Wang HF, Mísař Z, Jelínek E (1990) Thermobarometry, diffusion modelling and cooling rates of crustal garnet peridotites: two examples from the Moldanubian Zone of the Bohemian Massif. Lithos 25: 189-202

Medaris G Jr, Wang H, Jelínek E, Mihaljevič M, Jakeš $P(2005)$ Characteristics and origins of diverse Variscan peridotites in the Gföhl Nappe, Bohemian Massif, Czech Republic. Lithos 82: 1-23

Medaris LG Jr, BeArd BL, Jelínek E (2006a) Mantlederived, UHP garnet pyroxenite and eclogite in the Moldanubian Gföhl nappe, Bohemian Massif: a geochemical review, new $\mathrm{P}-\mathrm{T}$ determinations and tectonic interpretation. Int Geol Rev 48: 765-777

Medaris, LG Jr, Ghent ED, Wang HF, Fournelle JH, JELÍNEK E (2006b) The Spačice eclogite: constraints on the $\mathrm{P}-\mathrm{T}-\mathrm{t}$ history of the Gföhl granulite terrane, Moldanubian Zone, Bohemian Massif. Mineral Petrol 86: 203-220

Meisel T, Walker RJ, Morgan JW (1996) The osmium isotopic composition of the Earth's primitive upper mantle. Nature 383: 517-520

Meisel T, Walker RJ, Irving AJ (2001) Osmium isotopic compositions of mantle xenoliths: a global perspective. Geochim Cosmochim Acta 65: 1311-1323

MísAř Z, JELíneK E, JAKEŠ P (1984) Inclusions of peridotite, pyroxenite and eclogite in granulite rocks of preHercynian upper mantle and lower crust in the eastern Bohemian Massif (Czechoslovakia). Ann Sci Univ Clermont-Ferrand II 74: 85-95

NiCKel KG, Green DH (1985) Empirical geothermobarometry for garnet peridotites and implications for the nature of the lithosphere, kimberlites and diamonds. Earth Planet Sci Lett 73: 158-170

Norman MD (1998) Melting and metasomatism in the continental lithosphere: laser ablation ICPMS analysis of minerals in spinel lherzolites from eastern Australia. Contrib Mineral Petrol 130: 240-255

O’Neill HStC (1980) An experimental study of Fe-Mg partitioning between garnet and olivine and its calibration as a geothermometer: corrections. Contrib Mineral Petrol 72: 337

O'Neill HStC (1981) The transition between spinel lherzolite and garnet lherzolite, and its use as a geobarometer. Contrib Mineral Petrol 77: 185-194

O’Neill HStC, Wood BJ (1979) An experimental study of $\mathrm{Fe}-\mathrm{Mg}$ partitioning between garnet and olivine and its calibration as a geothermometer. Contrib Mineral Petrol 70: 59-70

Pearson DG, Irvine GJ, Ionov DA, Boyd FR, Dreibus GE (2004) Re-Os isotope systematics and platinum group element fractionation during mantle melt extraction: a study of massif and xenolith peridotite suites. Chem Geol 208: 29-59

Pfiffner OA, Ramsay JG (1982) Constraints on geological strain rates; arguments from strain rates of naturally deformed rocks. J Geophys Res 87 (B1): 311-321

Prior DJ, Boyle AP, Brenker F, Cheadle MC, Day A, Lopez G, Purezzo L, Potts GJ, Reddy S, Spiess R, Timms NE, Trimby PW, Wheeler J, Zetterstrom L (1999) The application of electron backscatter diffraction and orienta- 
tion contrast imaging in the SEM to textural problems in rocks. Amer Miner 84: 1741-1759

Reisberg L, Zhi X, Lorand JP, Wagner C, Peng Z, ZimMERMANN C (2005) Re-Os and S systematics of spinel peridotite xenoliths from east central China: evidence for contrasting effects of melt percolation. Earth Planet Sci Lett 239: 286-308

Schmädicke E, Evans BW (1997) Garnet-bearing ultramafic rocks from the Erzgebirge, and their relation to other settings in the Bohemian Massif. Contrib Mineral Petrol 127: 57-74

Schmidt MW, Poli S (1998) Experimentally based water budgets for dehydrating slabs and consequences for arc magma generation. Earth Planet Sci Lett 163: 361-379

Schulmann K, Kröner A, Hegner E, Wendt I, Konopásek J, LEXA O, ŠTíPSKÁ P (2005) Chronological constraints on the pre-orogenic history, burial, and exhumation of deep-seated rocks along the eastern margin of the Variscan Orogen, Bohemian Massif, Czech Republic. Amer J Sci 305: 407-448

Schulmann K, Konopásek J, Janoušek V, Lexa O, Lardeaux J M, Edel J B, Štípská P, Ulrich S (2009) An Andean type Palaeozoic convergence in the Bohemian Massif. C R Geosci 341: 266-286

Shirey SB, Walker RJ (1995) Carius tube digestions for low-blank rheniumñosmium analysis. Anal Chem 67: 2136-2141

Shirey SB, WALKER RJ (1998) The Re-Os isotope system in cosmochemistry and high-temperature geochemistry. Ann Rev Earth Planet Sci 26: 423-500

SkEMER P, KARATO S-I(2008) Sheared lherzolite xenoliths revisited. J Geophys Res 113: doi:10/1029.2007JB005286

Skemer P, Katayama I, Jiang Z, Karato S-I (2005) The misorientations index: development of a new method for calculating the strength of lattice preferred orientation. Tectonophysics 411: 157-167

Smith CS, Guttman L (1953) Measurement of internal boundaries in three-dimensional structures by random sectioning. Trans Am Inst Mining Eng 197: 81-87

Song S, Zhang L, Chen J, Liou JG, Niu Y (2005) Sodic amphibole exsolutions in garnet from garnet-peridotite, North Qaidam UHPM Belt, NW China: implications for ultradeep-origin and hydroxyl defects in mantle garnets. Amer Miner 90: 814-820

Strnad L, Mihaluevič M, ŠEBeK O (2005) Laser ablation and solution ICP-MS determination of rare earth elements in USGS BIR-1G, BHVO-2G and BCR-2G glass reference material. Geostand Geoanal Res 29: 303-314

SundBerg M, CoOper RF (2008) Crystallographic preferred orientation produced by diffusional creep of harzburgite: the effects of chemical interactions amongst phases during plastic flow. J Geophys Res 113 (B12208), doi: 10.1029/2008JB005618
TAYLOR WR (1998) An experimental test of some geothermometer and geobarometer formulations for upper mantle peridotites with application to the thermobarometry of fertile lherzolite and garnet websterite. Neu Jb Mineral, Abh 172: 381-408

Tikoff B, Fossen H (1993) Simultaneous pure and simple shear: the unifying deformation matrix. Tectonophysics 217: $267-283$

Tommasi A (1998) Forward modelling of the development of seismic anisotropy in the upper mantle. Earth Planet Sci Lett 160: 1-13

Toy VG, Newman J, Lamb W, Tikoff B (in print) The role of pyroxenites in formation of shear instabilities in the mantle: evidence from an ultramafic ultramylonite, Twin Sisters Massif, Washington. J Petrol, doi: 10.1093/ petrology/egp059

Ulrich S, MainPrice D (2005). Does cation ordering in omphacite influence development of lattice-preferred orientation? J Struct Geol 27: 419-431

van der Wal D, Chopra P, Drury M, Fits Gerald J (1993) Relationships between dynamically recrystallised grain size and deformation conditions in experimentally deformed olivine rocks. Geophys Res Lett 20: 1479-1482

VAN DER WAL D, VISSERS RLM (1993) Uplift and emplacement of upper mantle rocks in the western Mediterranean. Geology 21: 1119-1122

van Roermund HLM, Drury MR, Barnhoorn A, De Ronde A (2001) Relict majoritic garnet microstructures from ultra-deep orogenic peridotites in Western Norway. J Petrol 42: 117-130

VRÁna V, ŠTedrá V, FišERa M (2005) Petrology and geochemistry of the Běstvina granulite body metamorphosed at eclogite facies conditions, Bohemian Massif. J Czech Geol Soc 50: 95-106

Walker RJ, Carlson RW, Shirey SB (1989) Os, Sr, Nd, and $\mathrm{Pb}$ isotope systematics of southern African peridotite xenoliths - implications for the chemical evolution of the subcontinental mantle. Geochim Cosmochim Acta 53: 1583-1595

Walker RJ, Prichard HM, Ishiwatari A, Pimentel M (2002) The osmium isotopic composition of convecting upper mantle deduced from ophiolite chromites. Geochim Cosmochim Acta 66: 329-345

WARrEn JM, HirTh G (2006) Grain size sensitive deformation mechanisms in naturally deformed peridotites. Earth Planet Sci Lett 248: 438-450

Webber CE, Little TA, Newman J, Tikoff B (2008) Fabric superposition in upper mantle peridotite, Red Hills, New Zealand. J Struct Geol 30: 1412-1428

Wightman RH, Prior DJ, Little TA (2006) Quartz veins deformed by diffusion creep-accommodated grain boundary sliding during a transient, high strain rate event in the Southern Alps, New Zealand. J Struct Geol 28: 902-918 
Willner AP, Sebazungu e, Gerya TV, Maresch WV, Krohe A (2002) Numerical modelling of PT-paths related to rapid exhumation of high-pressure rocks from the crustal root in the Variscan Erzgebirge Dome (Saxony/ Germany). J Geodyn 33: 281-314

\section{Appendix - analytical methods}

\section{A.1. Electron probe microanalysis}

Minerals were analyzed by wavelength-dispersion spectrometry (WDS) with a Cameca SX50 instrument at the University of Wisconsin. Operating conditions were: $15 \mathrm{kV}$ accelerating voltage, $20 \mathrm{nA}$ beam current (Faraday cup), and beam diameter of $1 \mu \mathrm{m}$. Combinations of natural minerals and synthetic materials were used as standards for each of the mineral species, e.g. natural olivine for $\mathrm{Mg}, \mathrm{Fe}$, and $\mathrm{Si}$ and $\mathrm{Ni}$ metal for $\mathrm{Ni}$ in unknown olivine, synthetic spinel for $\mathrm{Mg}$ and $\mathrm{Al}$ and natural chromite for $\mathrm{Fe}$ and $\mathrm{Cr}$ in unknown spinel, and comparably appropriate combinations for pyroxenes and amphibole. Data reduction was performed by Probe for Windows software, utilizing the $\phi(\rho z)$ matrix correction of Armstrong (1988).

\section{A.2. Electron back-scattered diffraction}

EBSD data were collected from oriented, polished thin sections that had been subjected to further chemicalmechanical polishing for $\sim 20$ minutes with colloidal silica and very thinly carbon-coated to prevent specimen charging. Data were acquired on a Hitachi S3400N SEM at the University of Wisconsin-Madison and processed using HKL CHANNEL5 software. A general description of this method is provided by Prior et al. (1999). Crystallographic orientation data were collected using a step size of $15 \mu \mathrm{m},<1 / 3$ of the smallest grain size of the matrix material. Patterns were collected relatively slowly, to maximise quality, and indexed on the basis of $\geq 6$ Kikuchi bands so that only limited $(<<1 \%)$ amount of mis-indexing of crystal orientation could have occurred. Resultant data collection rates were 1 point every $\sim 0.4$ s. Data were processed (see Bestmann and Prior 2003) to produce microstructural maps, and orientation data sets based on one point per grain, where grains are separated by boundaries with misorientations $\geq 10^{\circ}$. Grains containing at least 3 analysis points (i.e. $\geq$
Wright TL, Doherty PC (1970) A linear programming and least squares computer method for solving petrologic mixing problems. Geol Soc Am Bull 81: 1995-2008

$40 \mu \mathrm{m}$ in diameter) were selected for plotting on LPO figures. This sampling scheme produces data directly comparable with data collected by universal stage techniques (e.g. Webber et al. 2008). LPO fabric plots were generated using the program PFCh5.app courtesy of D. Mainprice, and are presented on lower hemisphere equal area stereographic projections standard $\mathrm{X}-\mathrm{Y}-\mathrm{Z}$ fabric reference frame as described in the caption of Fig. 6 . Fabric strengths were quantified using the M-index of Skemer et al. (2005), which is a measure of the deviation of the distribution of uncorrelated misorientations from the expected random distribution in a crystal aggregate. Possible $\mathrm{M}$-indices range from 0 for a completely random distribution, to 1 for a single crystal. These calculations were performed using the matlab script Mindex_GUI.m (courtesy of P. Skemer).

\section{A.3. Wet chemical analysis}

Major and minor elements in whole-rock samples were determined by traditional wet-chemistry methods at the Faculty of Science, Charles University. Replicate analyses of reference material, e.g., PCC-1, yield an average precision of $\pm 5 \%(1 \sigma)$.

\section{A.4. Trace element ICP-MS analyses}

Whole-rock ICP-MS trace-element analyses were obtained using the methods of Strnad et al. (2005) at the Faculty of Science, Charles University. Clinopyroxene and garnet separates were prepared using a combination of heavy liquid and magnetic separations, which resulted in $>95 \%$ pure separates. Separates were then leached in hot acids $\left(\sim 60^{\circ} \mathrm{C}\right)$ to remove possible grain-boundary contamination, using the following leaching steps: garnet $-6 \mathrm{~N} \mathrm{HCl}$ for 1 day, $7 \mathrm{~N} \mathrm{HNO}_{3}$ for 1 day and $11 \mathrm{~N} \mathrm{HF}$ for $10 \mathrm{~min}$; clinopyroxene $-6 \mathrm{~N} \mathrm{HCl}$ for 1 hour and $6 \mathrm{~N}$ $\mathrm{HNO}_{3}$ for 1 hour. Trace-elements in clinopyroxene and garnet were measured by ICP-MS at Charles University, using the same procedures as mentioned above (Strnad et al. 2005). 


\section{A.5. $\mathrm{Rb}$-Sr and $\mathrm{Sm}-\mathrm{Nd}$ isotopes}

For isotope analyses, whole-rocks, pyroxenes and garnets were spiked with a mixed ${ }^{84} \mathrm{Sr}-{ }^{87} \mathrm{Rb}$ and ${ }^{149} \mathrm{Sm}-{ }^{150} \mathrm{Nd}$ tracer solution. All samples were digested in 52\% HF for seven days at $180{ }^{\circ} \mathrm{C}$ in a Teflon bomb surrounded by a steel jacket. Before digestion, garnets were leached in $6 \mathrm{M} \mathrm{HCl}$ (1 day), $7 \mathrm{M} \mathrm{HNO}_{3}$ (1 day) and $11 \mathrm{M} \mathrm{HF}$ (10 minutes) at $60{ }^{\circ} \mathrm{C}$ whereas pyroxenes were leached in $6 \mathrm{M} \mathrm{HCl}$ (1 hour) and $6 \mathrm{M} \mathrm{HNO}_{3}(1$ hour) at the same temperature. The whole-rock powders were not leached prior to digestion. Digested samples were dried and redissolved in $6 \mathrm{~N} \mathrm{HCL}$, dried again and redissolved in $2.5 \mathrm{~N} \mathrm{HCl} . \mathrm{Rb}, \mathrm{Sr}$ and light rare-earth element separation was accomplished on quartz columns by conventional ion exchange chromatography with a $5 \mathrm{ml}$ resin bed of Bio Rad AG 50W-X12, 200-400 mesh. Nd was separated from $\mathrm{Sm}$ and other rare-earth elements on quartz columns using $1.7 \mathrm{ml}$ Teflon powder coated with HDEHP, di(2-ethylhexyl) orthophosphoric acid, as cation exchange medium. All isotopic measurements were made by Thermal Ionization Mass Spectrometry, on a Finnigan MAT 262 mass spectrometer. Sr was loaded with a Ta-HF activator on pre-conditioned $\mathrm{W}$ filaments and was measured in single-filament mode. $\mathrm{Rb}$ was loaded with ultra-pure $\mathrm{H}_{2} \mathrm{O}$ on pre-conditioned Re-filaments and measurements were performed in a Re double filament configuration. Sm and $\mathrm{Nd}$ were loaded as phosphates and measured in a double Re-filament configuration mode. The ${ }^{87} \mathrm{Sr} r{ }^{86} \mathrm{Sr}$ ratios were normalized to ${ }^{86} \mathrm{Sr} /{ }^{88} \mathrm{Sr}=0.1194$, the ${ }^{143} \mathrm{Nd} /{ }^{144} \mathrm{Nd}$ ratios to ${ }^{146} \mathrm{Nd} /{ }^{144} \mathrm{Nd}=0.7219$, and $\mathrm{Sm}$ isotopic ratios to ${ }^{147} \mathrm{Sm} /{ }^{152} \mathrm{Sm}=0.56081$. Analyses of two different loads of La Jolla standard gave ${ }^{143} \mathrm{Nd} /{ }^{144} \mathrm{Nd}$ ratios of $0.511842 \pm 0.000008$ and $0.511833 \pm 0.000008$ (errors are $2 \sigma_{\mathrm{m}}$ ) while two analyses of the NBS $987 \mathrm{Sr}$ standard yielded a ${ }^{87} \mathrm{Sr} /{ }^{86} \mathrm{Sr}$ ratio of $0.710259 \pm 0.000010$ and $0.710246 \pm 0.000009\left(2 \sigma_{\mathrm{m}}\right)$. Total procedural blanks (chemistry and loading) were $125 \mathrm{pg}$ for $\mathrm{Sr}, 35 \mathrm{pg}$ for $\mathrm{Nd}$ and $4 \mathrm{pg}$ for $\mathrm{Sm}$. Single stage model-ages $\left(\mathrm{T}_{\mathrm{DM}}\right)$ were calculated with depleted present-day parameters
${ }^{143} \mathrm{Nd} /{ }^{144} \mathrm{Nd}=0.513151$ and ${ }^{147} \mathrm{Sm} /{ }^{144} \mathrm{Nd}=0.219$ (Liew and Hofmann 1988). ${ }^{143} \mathrm{Nd} /{ }^{144} \mathrm{Nd}$ ratios are quoted in the $\varepsilon N d$ notation of DePaolo and Wasserburg (1976) as deviations from a chondritic reference (CHUR) with present-day ${ }^{143} \mathrm{Nd} /{ }^{144} \mathrm{Nd}=0.512638$ (Jacobsen and Wasserburg 1980). Least-square regression of the $\mathrm{Sm}-\mathrm{Nd}$ isotopic data with assessment of fit using the mean square of the weighted deviates (MSWD), were calculated after Ludwig (2003).

\section{A.6. Analyses of highly siderophile elements (HSE)}

HSE concentrations and osmium isotopic compositions were obtained at the University of Maryland. Whole-rock powder $(\sim 2 \mathrm{~g})$ was mixed with Re-Os and Ir-Ru-Pt-Pd spikes and dissolved in Carius tubes using reverse concentrated aqua-regia at $280{ }^{\circ} \mathrm{C}$ for $2-3$ days (Shirey and Walker 1995). After digestion, osmium was separated using solvent extraction by $\mathrm{CCl}_{4}$ and back reduction to $\mathrm{HBr}$ (Cohen and Waters 1996), and the final fraction was purified by microdistillation (Birck et al. 1997). The remaining HSE were separated by anion exchange chromatography.

Os concentration and isotopic composition were analyzed by Negative Thermal Ionization Mass Spectrometry (N-TIMS) on a VG Sector 54 instrument, using an electron multiplier in a peak jumping mode. The measured Os isotopic ratios were corrected for mass fractionation using ${ }^{192} \mathrm{Os} /{ }^{188} \mathrm{Os}=3.08271$ (Shirey and Walker 1998). External precision was monitored using an in-house UMCP standard solution and was better than $\pm 0.3 \%(2 \sigma)$. Iridium, $\mathrm{Ru}, \mathrm{Pt}, \mathrm{Pd}$ and $\mathrm{Re}$ were analyzed using a Nu Plasma multi-collector ICP-MS with twothree electron multipliers in a static mode. The isotopic fractionation of corresponding elements was corrected using a linear law and in-house $\mathrm{Ir}, \mathrm{Ru}, \mathrm{Pd}, \mathrm{Pt}$ and $\mathrm{Re}$ standard UMCP solutions $(0.2-0.3 \mathrm{ppb})$ that were run with samples. HSE measurements are estimated to be accurate and precise to $\pm 5 \%$. 
